Review

\title{
How Reliable Is the Electrochemical Readout of MIP Sensors?
}

\author{
Aysu Yarman * and Frieder W. Scheller * \\ Institute of Biochemistry and Biology, University of Potsdam, Karl-Liebknecht-Strasse 24-25, \\ 14476 Potsdam, Germany \\ * Correspondence: aysu.yarman@yahoo.de (A.Y.); fschell@uni-potsdam.de (F.W.S.)
}

Received: 14 April 2020; Accepted: 6 May 2020; Published: 8 May 2020

\begin{abstract}
Electrochemical methods offer the simple characterization of the synthesis of molecularly imprinted polymers (MIPs) and the readouts of target binding. The binding of electroinactive analytes can be detected indirectly by their modulating effect on the diffusional permeability of a redox marker through thin MIP films. However, this process generates an overall signal, which may include nonspecific interactions with the nonimprinted surface and adsorption at the electrode surface in addition to (specific) binding to the cavities. Redox-active low-molecular-weight targets and metalloproteins enable a more specific direct quantification of their binding to MIPs by measuring the faradaic current. The in situ characterization of enzymes, MIP-based mimics of redox enzymes or enzyme-labeled targets, is based on the indication of an electroactive product. This approach allows the determination of both the activity of the bio(mimetic) catalyst and of the substrate concentration.
\end{abstract}

Keywords: molecularly imprinted polymers; electropolymerization; direct electron transfer; catalysis; redox marker; gate effect

\section{Introduction}

Over the past decades, increasing attention has been paid to the fast, selective and cost-effective detection and determination of analytes in many areas, including clinical diagnostics, pharmaceutical and environmental analysis, food control and security. Well-established laboratory-based (bio)analytical methods achieved great breakthroughs due to the highly specific interactions involved in most biological processes, e.g., the antigen-antibody interaction, substrate conversion by the action of enzymes and the sequence-specific hybridization of nucleic acids [1].

Nevertheless, biochemical reagents also have some drawbacks, such as stability under harsh conditions (high temperature, organic solvents, limited $\mathrm{pH}$ range), reusability and animal usage in preparation (antibodies). Starting from supramolecular chemistry, molecularly imprinted polymers (MIPs) have been created, which potentially overcome these drawbacks [2-8]. They are prepared by polymerizing functional monomers in the presence of a target analyte (template). The subsequent removal of the template from the polymer results in the formation of cavities with a molecular memory mirroring the size and shape of the template (Figure 1). MIPs mimic the binding sites of antibodies by substituting the amino acid scaffold for synthetic polymers. Furthermore, catalytically active MIPs containing metal ions or prosthetic groups of oxidoreductases have been developed, which exhibit enzyme-like activity towards substrates $[9,10]$. The polymer scaffold of the MIP provides specificity by substrate binding to the cavities while the metal complex is the reactive center. The performance of MIPs has also been markedly enhanced by incorporating nanomaterials [11,12] and, as a new trend, by integration in metal organic frameworks (MOFs) $[13,14]$. 


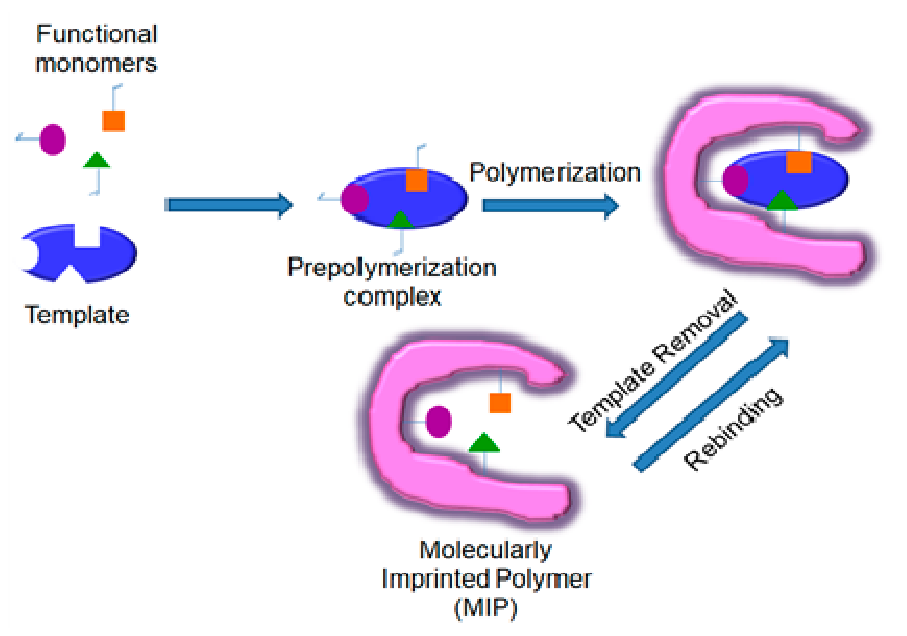

Figure 1. Schematic representation of MIP preparation.

For a good analytical performance of the sensor, the MIP should be placed immediately on the surface of the electrode. Two different procedures for the preparation of MIP sensors have been described in the literature [15].

(i) In the first procedure, the MIP is separately synthesized and then immobilized on the transducer surface. In the past, MIPs were most frequently synthesized using bulk polymerization. As a result, monolithic materials are produced, which are then ground into smaller particles. The major disadvantage of bulk polymerization is the bad accessibility and inhomogeneity of the binding pockets, which leads to a longer template removal time and slow rebinding. To overcome these problems, different forms of MIPs, such as micro- or nanobeads, nanoparticles or nanospheres have been prepared [16-19].

For the integration of MIPs in the body of the sensor, different methods have been used $[15,20,21]$. The simplest approach is drop coating [22]. Furthermore, spin coating or spray coating have been applied [23]. Grafting is another approach used for the incorporation of the MIPs [24]. In addition to the described approaches, MIPs can also be integrated via the preparation of composite membranes or layer-by-layer assembly $[15,20]$.

(ii) In the second procedure, the MIP-based recognition layer is directly formed on the transducer. In addition to the formation of an MIP layer by self-polymerization [25] and the microcontact imprinting of a soft polymer cover layer [26], electropolymerization is the most straightforward way to prepare MIPs directly on the conductive surface of a transducer, e.g., on an electrode, QCM or SPR chip [15,20,27]. An advantage of electrosynthesis is that the film thickness can be adjusted by varying the charge passed during the polymerization. The selection of the solvent and supporting electrolyte and the regime of potential applications influence the morphology of the polymer layer [20,28]. Furthermore, the application of potential pulses is a simple method for removing the template after the MIP synthesis.

Molecular recognition by MIPs has been coupled in biomimetic sensors with a whole arsenal of transducers [20,28-36]. Among them, electrochemical and optical techniques clearly dominate [31,37]. In addition, piezoelectric [38-40], thermal [41,42] and micromechanical [43,44] transducers have been applied in MIP sensors. All steps of MIP synthesis, and of the measurement, can be analyzed by methods directly indicating the presence of the target molecule in the MIP layer, or by indirect methods evaluating the change in the signal of a marker $[1,31,45]$. The direct detection of the template molecules by the redox conversion at an electrode [46], intrinsic fluorescence of the target or of a label [47], Raman and FTIR spectroscopy [48] or surface-enhanced infrared absorption (SEIRA) spectroscopy [49] specifically indicate the presence of the template in the MIP during the removal and rebinding of the target. In contrast, surface plasmon resonance (SPR), quartz crystal microbalance (QCM), and capacitor- or thermistor-based sensing systems reflect specific binding, nonspecific adsorption to the polymer surface and other types of changes in the chemical environment $[1,33,42,50,51]$. 
Another important aspect is the assay format. The determination of thermodynamic parameters, e.g., the binding constant, requires the generation of the measuring signal under equilibrium conditions, i.e., the affinity sensor is in a target-containing solution. Only for binder-target pairs, with a very low rate of dissociation, can the measurement be performed in a target-free solution. On the other hand, for "dynamic" systems, the dissociation rate can be determined by the decay of the signal after the removal of the target, which is an approach frequently used for SPR and QCM sensors [40,52].

In this review, the focus will be on the electrochemical readout of MIP sensors.

\section{Electrochemical Readout}

The electrochemical readout of biosensors started in 1962 with the first glucose sensor by Leland Clark [53]. Enzyme electrodes allow the indirect measurement of an electroinactive analyte by indicating the concentration change of an electroactive reaction partner, e.g., oxygen, hydrogen peroxide, a redox marker or the change of the $\mathrm{pH}$. Electrochemical methods have been successfully transferred to immunosensors [54] and nucleic acid arrays [55]. Electrochemical biomimetic sensors based on MIPs or aptamers have also been developed [56].

Among the electrochemical approaches, a comparably low number of potentiometric MIP sensors, capacitors or field effect transistors have been presented, while voltammetric methods are widely used [28,33,57-59]. The potential window of voltammetric sensors is restricted by anodic oxygen evolution and cathodic hydrogen generation. This potential region is larger for carbon-based electrodes as compared with noble metal electrodes. The measuring potential of the electrode is decisive for the selectivity of the sensor. Any electroactive substance with a lower redox potential is electrochemically converted, thus contributing to the electrode signal. Pulse methods like differential pulse voltammetry (DPV) and square wave voltammetry (SWV) are effective methods to suppress electrochemical interferences and to increase sensitivity by eliminating the charging current. Additionally, a large spectrum of nanomaterials, including nanoparticles, carbon nanotubes and graphene, has been successfully applied to improve the analytical performance of electrochemical sensors, including MIPs [11,12].

Electrochemical methods are especially appropriate for the direct quantification of redox-active analytes, and for the indication of redox enzymes or enzyme mimics, by measuring the formation of electroactive products. For the measurement of electroinactive analytes by affinity sensors, redox-active labels or enzyme "tracers" have been used to generate an electrochemical signal. As a general approach for all affinity sensors, the modulation of the electrochemical signal of a redox marker has been introduced. These electrochemical approaches have been adapted for the readout of MIP sensors (Figure 2) [1,20,31,37].

Electroactive analytes

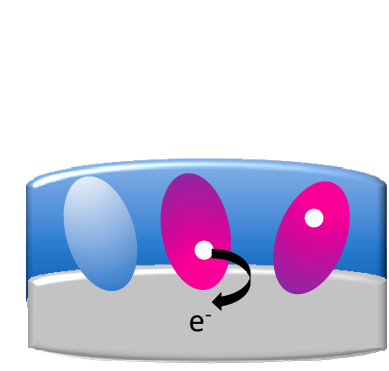

Faradaic current
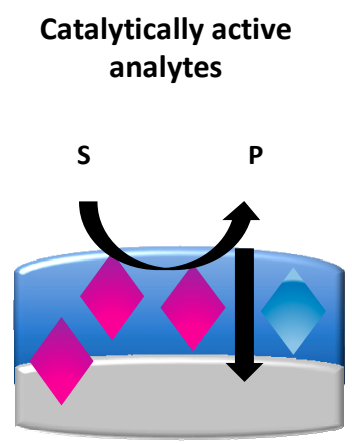

Product formation

\section{Redox-inactive analytes}

$\left[\mathrm{Fe}(\mathrm{CN})_{6}\right]^{3-}$ or $\left[\mathrm{Ru}\left(\mathrm{NH}_{3}\right)_{6}\right]^{2+}$

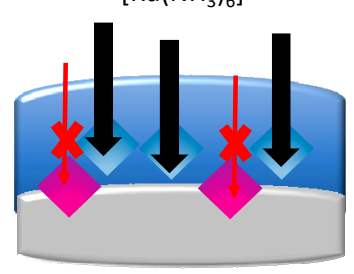

Permeation of redox marker

Figure 2. The main approaches used in electrochemical readouts of MIP-based sensors. 
(i) When the targets are redox-active, the faradaic current is measured, which is based on the direct electron transfer (DET) between the target and the underlying electrode.

(ii) In the case of enzyme targets, catalytically active MIPs or enzyme-labeled targets, the enzymatic activity of the MIP layer is detected via the generation of a redox-active product at the electrode surface.

(iii) Most of the research covers the flux of a redox marker. The signal modulated by the target binding is detected at the underlying electrode surface.

\subsection{Electroactive Analytes}

The most specific detection of rebinding to the MIP is the electrochemical conversion of the analyte. In this case, the signal originates from the template reaching to the electrode surface. The lack of selectivity may originate from "nonspecific pores" in the polymer layer, but not from the insufficient selectivity of the imprinted sites. The MIP film acts as a "molecular filter" on the electrode surface, which discriminates the constituents of the sample according to the size and shape of the molecules. This "filtering" leads to a marked improvement in the specificity as compared with the bare electrode. However, the partial "blockage" of the electrode surface decreases the sensitivity as compared with the bare electrode. The integration of nanomaterials such as nanoparticles, carbon nanotubes or graphene in the MIP layer increases the active surface area, thus enhancing sensitivity [11].

This measuring principle has been applied to a broad spectrum of low molecular-weight-substances, such as drugs (tamoxifen, paracetamol and L-DOPA [60-62]), veterinary drugs [63], hormones [64], chemicals (pesticides [65,66] and mycotoxins [67]) or drugs of abuse [68].

As early as 1995, Kriz and Mosbach described an amperometric detection system for morphine based on MIPs [69]. MIP particles were immobilized on a Pt electrode via agarose. The measurement involved two steps. In the first step, morphine was bound to the MIP, resulting in an increase in current. In the next step, after signal stabilization, the electroinactive competitor, codeine, was added to the measuring solution, which caused the release of morphine from the MIP, resulting in a further increase in current due to the oxidation of morphine.

Another frequently applied voltammetric method for the detection and determination of electroactive analytes is differential pulse voltammetry. In 2007, Ozcan and Sahin developed an MIP sensor for the analgesic and antipyretic drug paracetamol [61]. The MIP was prepared by the electropolymerization of pyrrole in the presence of the drug on a graphite electrode. They evaluated the performance of the MIP by means of DPV. The sensor showed two linear regions: $5 \mu \mathrm{M}-0.5 \mathrm{mM}$ and $1.25-4.5 \mathrm{mM}$. The limit of detection (LOD) was calculated to be $0.79 \mu \mathrm{M}$. They also showed that the presence of a two-fold excess of potential interferences like glucose, phenacetin, dopamine, ascorbic acid and phenol did not influence the paracetamol response.

Furthermore, different nanomaterials were incorporated into the MIP sensors to enhance the signal [11,12]. For example, Li et al. applied Ag/N-doped reduced graphene oxide (Ag/N-RGO) in the MIP sensor for the determination of salbutamol, which is an $\beta 2$-adrenergic agonist [70]. The MIP was prepared on the Ag/N-RGO-modified glassy carbon electrode (GCE) via electropolymerization. Cyclic voltammetric measurements demonstrated that in a $0.1 \mathrm{mM}$ salbutamol solution, the lowest signal was obtained with bare GCE, whereas Ag/N-RGO-MIP-GCE showed the highest signal. DPV was applied for the quantitative determination. The linear range was found to be $0.03-20 \mu \mathrm{M}$ with an LOD of $7 \mathrm{nM}$.

In addition to disk or wire electrodes, screen-printed electrodes have also widely been applied in MIP sensors. Couto et al. have recently presented an MIP sensor for the direct detection of ecstasy (MDMA: 3,4-methylenedioxymethamphetamine), which is one of the most common narcotics (Figure 3) [68]. The sensor was prepared on a screen-printed carbon electrode by electropolymerization in a solution of o-phenylenediamine and MDMA. The binding of MDMA was detected by square wave voltammetry. The sensor exhibited a linear response of up to $0.2 \mathrm{mM}$ with an LOD of $0.79 \mu \mathrm{M}$. Moreover, selectivity studies have been performed with structurally similar substances. The selectivity factor, which is the ratio of the MDMA peak current and the interfering substances, has been calculated 
to be 5.6 and 2.8 for dopamine and tyramine, respectively. They further applied the sensor in biological fluids.

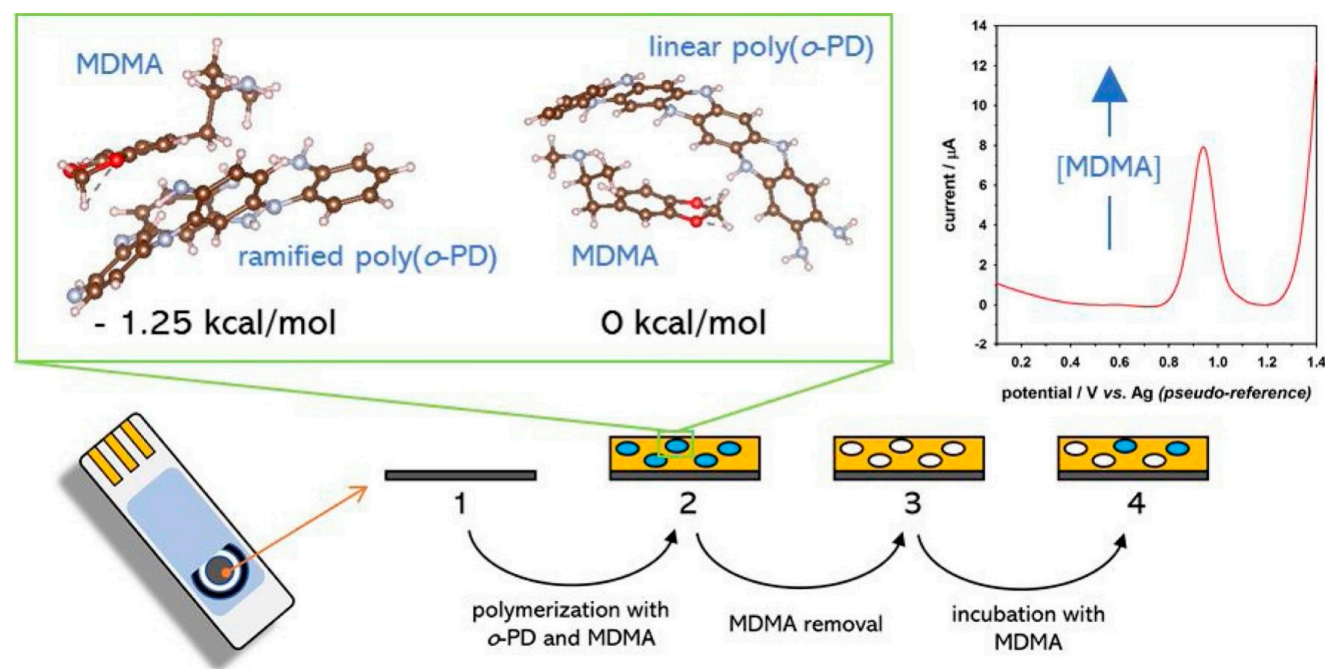

Figure 3. Schema of ecstasy-imprinted polymer on a screen-printed electrode and direct electrochemical detection of ecstasy (MDMA: 3,4-methylenedioxymethamphetamine) binding. Reprinted by permission from [68].

Moghadam et al. prepared an MIP sensor on a screen-printed carbon electrode for the determination of the antibiotic oxacillin (OXC) [71]. Prior to the electropolymerization of aniline, gold nanourchin and graphene oxide were immobilized on the electrode. The linear response obtained by means of DPV was in the concentration range of $0.7-575 \mathrm{nM}$ and the LOD was determined to be $0.2 \mathrm{nM}$.

Moro et al. developed an MIP sensor for the $\beta$-lactam antibiotic cefquinome (CFQ) on a multi-walled carbon nanotube-modified graphite screen-printed electrode [63]. The sensor showed a linear response $(50 \mathrm{nM}-50 \mu \mathrm{M})$ only after applying two steps, i.e., incubation in CFQ and measurement in fresh CFQ-free solution.

Recently, Amatatongchai et al. exploited screen-printing technology on a paper-based system for the detection of serotonin [22]. Nanosized MIP particles were prepared by encapsulating $\mathrm{Fe}_{3} \mathrm{O}_{4} @ \mathrm{Au}$ nanoparticles with silica, which was imprinted by the sol-gel method. These particles were then drop-casted onto the graphite electrode of the paper-based device. Serotonin was quantified by linear sweep voltammetry. The linear range and LOD were determined to be $0.01-1000 \mu \mathrm{M}$ and $0.002 \mu \mathrm{M}$, respectively. Furthermore, the device showed no interference for ascorbic acid, uric acid, dopamine, glucose norepinephrine or ions like $\mathrm{Mg}^{2+}$ and $\mathrm{Ca}^{2+}$.

The simultaneous determination of several analytes is of great interest in some areas, such as clinical and pharmaceutical analysis. MIPs have been applied in the simultaneous determination of different analytes as well [72-74]. Zheng et al. developed an electrochemical MIP sensor for the direct detection of uric acid and tyrosine [72]. The MIP was prepared on a reduced graphine oxide-modified electrode using a novel monomer of 2-amino-5-mercapto-1,3,4-thiadiazole and a dual template via electropolymerization. DPV was applied to characterize the analytical performance of the sensor. The MIP exhibited two linear regions for uric acid, i.e., $0.01-1 \mu \mathrm{M}$ and $4-100 \mu \mathrm{M}$ with an LOD of $0.0032 \mu \mathrm{M}$. Two linear regions were also observed for tyrosine, i.e., $0.1-10 \mu \mathrm{M}$ and $40-400 \mu \mathrm{M}$ with an LOD of $0.046 \mu \mathrm{M}$. In addition, a 50-fold concentration of the potential interferences dopamine, epinephrine, adenine, xanthine, ascorbic acid and glucose had a negligible effect on uric acid and tyrosine sensing by the MIP sensor, whereas with a reduced graphene oxide-modified glassy carbon electrode, pronounced interferences were found. In another work, an MIP sensor for rifampicin (RIF) and isoniazid (INZ) was developed [74]. Prior to the electropolymerization of pyrrole, the glassy carbon electrode was modified with a copper metal organic framework/mesoporous carbon composite. 
This modification enhanced the sensitivity of the sensor. Adsorptive stripping differential pulse voltammetry showed that the sensor's response was linearly dependent for both RIF and INZ on the concentration in the range of $0.08-85 \mu \mathrm{M}$ and the LODs were determined to be $0.28 \mathrm{nM}$ and $0.37 \mathrm{nM}$ for RIF and INZ, respectively. Moreover, simultaneous determinations of the drugs were realized in serum, urine and pharmaceutical dosages as well as in aqueous solutions.

It is known that the anodic oxidation of phenolic substances generates a polymer film, which causes a decrease in sensitivity by the "fouling" of the electrode surface. In order to prevent this adverse effect, the analyte was converted in a preceding enzymatic reaction into a product, which was indicated at a lower potential at the electrode than the polymer formation [75,76]. Yarman and Scheller have applied this approach for an electrochemical MIP sensor for the analgesic drug aminopyrine, which is converted by horseradish peroxidase to aminoantipyrine in a layer on the top of an aminoantipyrine MIP [75]. Therefore, aminoantipyrine was used as the target of the electrosynthesized MIP. The rebinding of aminoantipyrine to the aminoantipyrine-imprinted electropolymer was measured using the oxidation current at $0.5 \mathrm{~V}$. The amperometric current response of the MIP-covered glassy carbon electrode was linearly dependent on the concentration up to $110 \mu \mathrm{M}$. The imprinting factor was calculated to be 6.67. The highest signal was observed for the template as compared to ascorbic acid, uric acid and caffeine. Furthermore, an HRP-catalyzed reaction allowed a measurement at a lower potential, i.e., $0 \mathrm{~V}$, which led to the complete elimination of interfering substances.

Only a limited number of MIPs for redox enzymes and metalloproteins exploiting DET have been published. This measuring principle is restricted to "extrinsic" redox enzymes with surface-exposed redox centers, which exchange electrons with electrodes without soluble mediators [77]. The first MIP exhibiting DET was developed for the hemeprotein cytochrome c by Scheller's group [46]. The target protein was pre-adsorbed at a negatively charged self-assembled monolayer (SAM) of mercaptoundecanoic acid (MUA) prior to the polymer deposition (Figure 4). The surface concentration of cytochrome c, which was calculated from cyclic voltammetric measurements, increased linearly up to $4 \mu \mathrm{M}$. Furthermore, competition experiments with other proteins (bovine serum albumin, myoglobin and lysozyme) demonstrated that the MIP had preferential binding to its target, cytochrome c. Following this procedure, an MIP was synthesized around a more complex protein, hexameric tyrosine-coordinated heme protein (HTHP), which was also immobilized electrostatically on a negatively charged SAM prior to electopolymerization [78]. The MIP-bound enzyme showed both DET and enzymatic substrate conversion. On the other hand, reports about MIPs for the hemeprotein hemoglobin $(\mathrm{Hb})$ with the readout by DET are questionable since the formal potential reported is far too negative as compared with the value of the native protein $[79,80]$.

A)

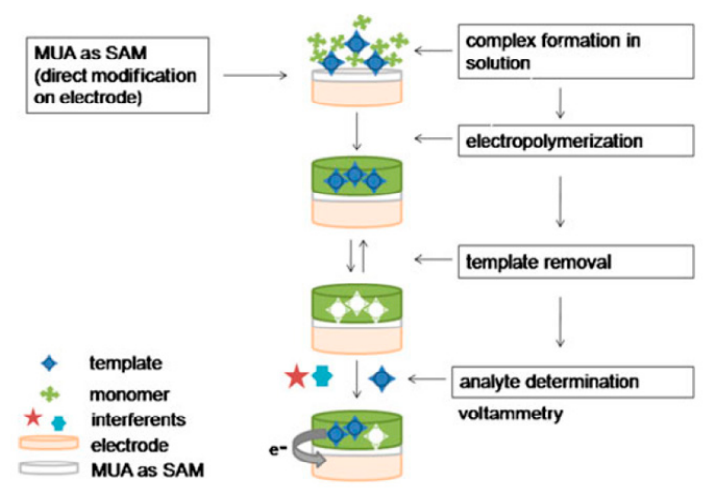

B)

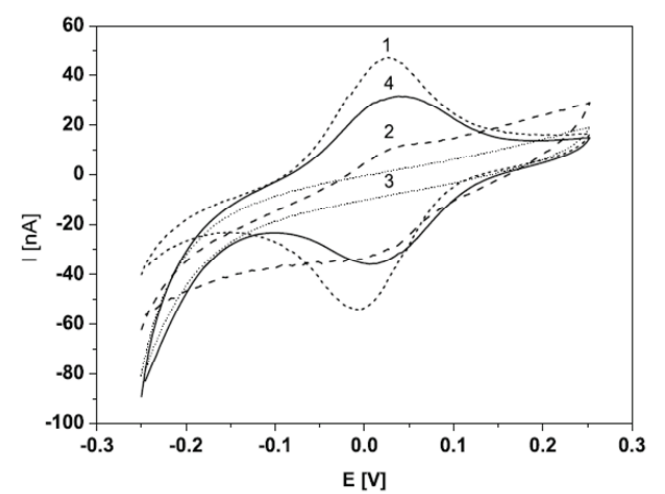

Figure 4. (A) Workflow of the preparation of the cytochrome c MIP and (B) the electrochemical readout indicating the DET at the MUA-covered Au electrode (1), after electropolymerization (2), after template removal (3) and rebinding (4). Reprinted by permission from [46]. 


\subsection{Catalytically Active Analytes}

\subsubsection{Enzymes and Enzyme-Labeled Analytes}

For biocatalysts, MIP synthesis, template removal and the rebinding of the analyte can be quantified by evaluating the biocatalytic activity of the MIP sensor. The formation of a colored reaction product was indicated for trypsin, human $\mathrm{Hb}$ and cytochrome P450 BM3 using optical methods [81-83]. Furthermore, the indication of a redox-active reaction product at the electrode has been applied for the characterization of template removal and rebinding for electrochemical MIP sensors. This principle has been successfully applied for acetylcholinesterase (AChE), laccase, tyrosinase, butyrylcholinesterase (BuChE), and horseradish peroxidase (HRP) [84-88]. The indication of the surface activity of enzymes brought about measuring ranges of the respective MIP sensors in the picomolar to micromolar range. For the highly active $\mathrm{BuChE}$, the enzymatic activity was measured via the anodic oxidation of thiocholine, which is the reaction product of butyrylthiocholine [87]. The sensor exhibited a linear response between $50 \mathrm{pM}$ and $2 \mathrm{nM}$ concentrations of BuChE with an LOD of $14.7 \mathrm{pM}$.

The surface activity sums up the substrate conversion by the enzyme molecules within the binding cavities and that of the nonspecifically adsorbed enzyme at the non-imprinted polymer surface. On the other hand, the generation of a catalytic current upon addition of the (co)substrate proves that the protein approaches the electrode surface with a "productive orientation" for DET. This approach was introduced by Reddy et al. for catalytic oxygen reduction in the presence of $\mathrm{Hb}[89]$ and was further adapted to myoglobin (Figure 5) [90] and bioelectrocatalytic peroxide reduction by MIP-bound HTHP [78].

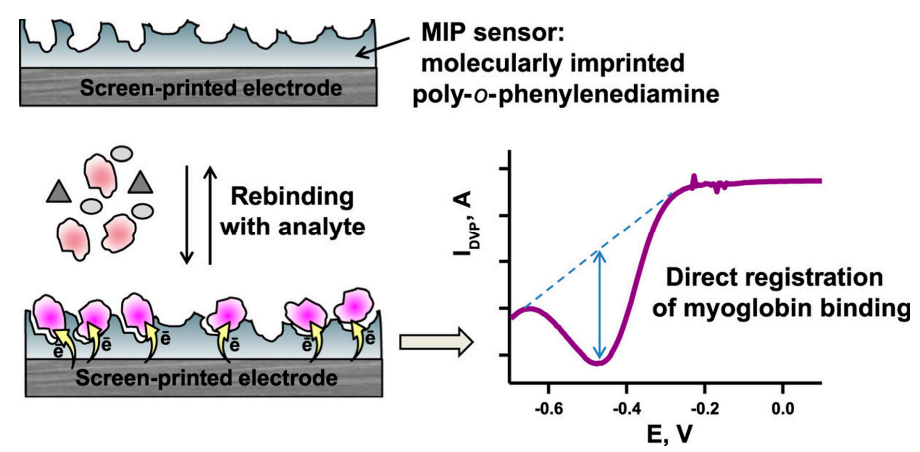

Figure 5. Schema of MIP preparation and the detection of myoglobin binding. Reprinted by permission from [90].

Moreover, the coupling of MIPs with enzymes can enhance the analytical performance of biomimetic sensors. Signal generation by enzyme-labeled "tracers" has been applied analogously to competitive immunoassays in MIP sensors, e.g., for oxytetracycline (OTC) [91,92]. Glucose oxidase (GOD)-labeled OTC was used as tracer in a competitive assay format and the enzymatic activity was electrochemically evaluated (Figure 6). DPVs showed a concentration-dependent signal between 0 and $0.4 \mu \mathrm{M}$ with an LOD of $0.33 \mathrm{nM}$ [92]. 


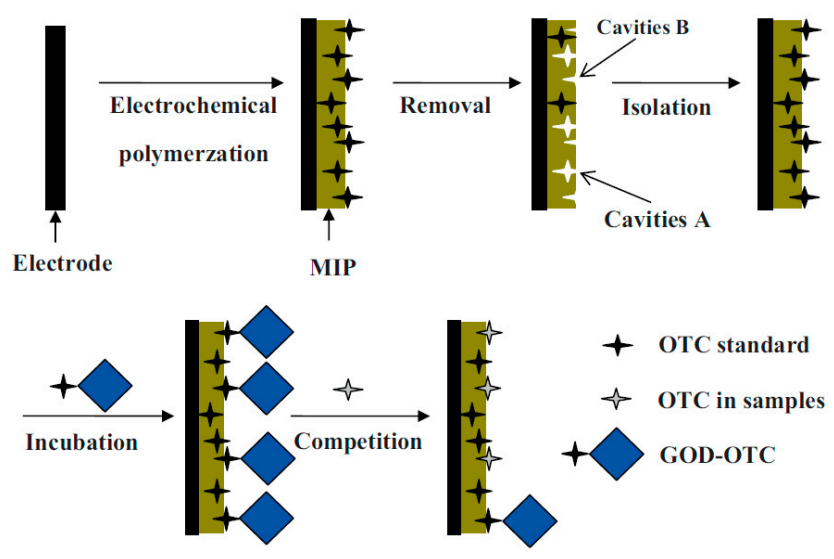

Figure 6. Schema of MIP preparation for oxytetracycline (OTC) and the principle of detection based on the glucose oxidase tracer (GOD-OTC). Reprinted by permission from [92].

The same group further enhanced the sensitivity of the MIP sensor for OTC by combining their approach with Prussian Blue (PB) [93], which reduces in neutral solutions hydrogen peroxide [94]. The MIP was prepared by electropolymerization in a solution containing OTC, polypyrrole, $\mathrm{FeCl}_{3}$, $\mathrm{K}_{3}\left[\mathrm{Fe}(\mathrm{CN})_{6}\right]$ and $\mathrm{KCl}$. It was demonstrated by DPVs that an increasing amount of OTC resulted in a decreased formation of $\mathrm{H}_{2} \mathrm{O}_{2}$, which is caused by the reduced amount of bound OTC-GOD. The sensor showed two linear ranges, i.e., $0-0.1 \mu \mathrm{M}$ and $0.1-1 \mu \mathrm{M}$ with an LOD of $230 \mathrm{fM}$.

An enzyme-labeled tracer has been further applied in an MIP sensor for the detection of streptomycin (STR), which has been used for the treatment of various bacterial infections [95]. The MIP sensor was prepared electrochemically on a gold electrode by copolymerizing aniline and o-phenylenediamine in the presence of STR. In comparison to the OTC-MIP, the measuring procedure does not include a separation step, but GOD-STR and STR mixtures were incubated for rebinding together. The hydrogen peroxide current was measured by DPV. The sensor had a linear response in the concentration range between 0.01 and $10 \mathrm{ng} / \mathrm{mL}$ STR and an LOD of $7.0 \mathrm{pg} / \mathrm{mL}$ was determined. The application of enzyme-labeled tracers in competitive formats allows for the extension to electroinactive analytes. However, the reagent costs are higher than for "direct" electrochemical sensors and the enzyme can hinder the interaction of the analyte with the MIP cavities and it may interact with the polymer surface.

\subsubsection{Catalytically Active MIPs}

In addition to binding MIPs, which mimic the function of antibodies, enzyme mimics based on MIPs have also been developed. This field was pioneered by Wulff in 1972 [2]. By analogy with catalytically active antibodies, an analog of the transition state of the catalyzed reaction is applied as the template [96-99]. Efficient catalysis has been realized for splitting esters, carbonates and carbamates. These MIPs mimic catalysis by hydrolases. On the other hand, oxidoreductase mimics have been synthesized by integrating metal ions or metal complexes into the polymer matrix of MIPs $[9,100]$. As described for enzyme electrodes, the measuring signal is generated by the indication of an electroactive product or the consumption of a cosubstrate-like oxygen or peroxide.

Lakshmi et al. presented an electrochemical MIP sensor for catechol and dopamine using a $\mathrm{Cu}^{2+}$-containing layer of poly(N-phenylethylene diamine methacrylamide), which oxidized the template by ambient oxygen [101]. The polymer mimics the activity of the enzyme tyrosinase. The sensor's response to catechol was linear up to $144 \mu \mathrm{M}$ with an LOD of $228 \mathrm{nM}$. Furthermore, resorcinol, hydroquinone and serotonin did not interfere. However, for the regeneration of the sensor, reloading with $\mathrm{Cu}^{2+}$ was required. In another work, the enzyme nitroreductase was mimicked by a copper-melanin complex, which was used as the functional monomer. The MIP was prepared by 
electropolymerization on a chitosan capped AuNP-modified glassy carbon electrode in the presence of the drug metronidazole. The MIP sensor generated a concentration-dependent electrocatalytic current for the reduction of the nitro groups.

A mimic of the selenoenzyme glutathione peroxidase was built up by polymerizable amino acid derivatives as functional monomers and acryloyloxypropyl 3-hydroxypropyl telluride as the catalytic center [102]. The polymerization was performed in the presence of glutathione as a template. The MIP showed both specific substrate binding and peroxidase-like activity.

The integration of redox-active groups of enzymes into the polymer scaffold is more straightforward than the application of simple metal complexes for the synthesis of enzyme mimics based on MIPs. Especially hemin, the active site of peroxidases and cytochrome P450 enzymes, has frequently been used (Figure 7). An MIP for homovalinic acid (HVA) which shows peroxidatic activity, was prepared by the copolymerization of hemin and HVA as a template [103]. It specifically bound to HVA and catalyzed its oxidation by hydrogen peroxide with a higher activity than towards (p-hydroxyphenyl)acetic acid and (p-hydroxyphenyl)propionic acid. Similar peroxidase mimics for the oxidation of p-aminophenol, serotonin or epinephrine were prepared by the bulk polymerization of methacrylic acid and integrated in a flow injection analysis (FIA) system with electrochemical detection [104-106]. Moreover, the FIA system has been applied for the measurement of serotonin in blood serum. In another work, chloroperoxidase-like activity towards 2,4,6-trichlorophenol (TCP) was demonstrated by Díaz-Díaz et al. for an MIP, which consisted of hemin as the catalytic center, TCP as the template and 4-viniylpyridine as a functional monomer [107]. Structurally similar substances did not influence the peroxide-dependent oxidation of TCP. Zhang et al. developed a hemin-containing dehalogenase-mimicking MIP, which indicated the formation of o-chlorobenzoquinone, the product of the peroxide-dependent reaction of 2,4-dichlorophenol, with an LOD of $1.6 \mu \mathrm{M}$ [108]. Additionally, a peroxidase-mimicking MIP was prepared by using hemin as the catalytic center and 5-hydroxyindole-3-acetamide (5-HIAA) as a template [109]. It exhibited high activity towards the tumor marker 5-hydroxyindole-3-acetic acid.

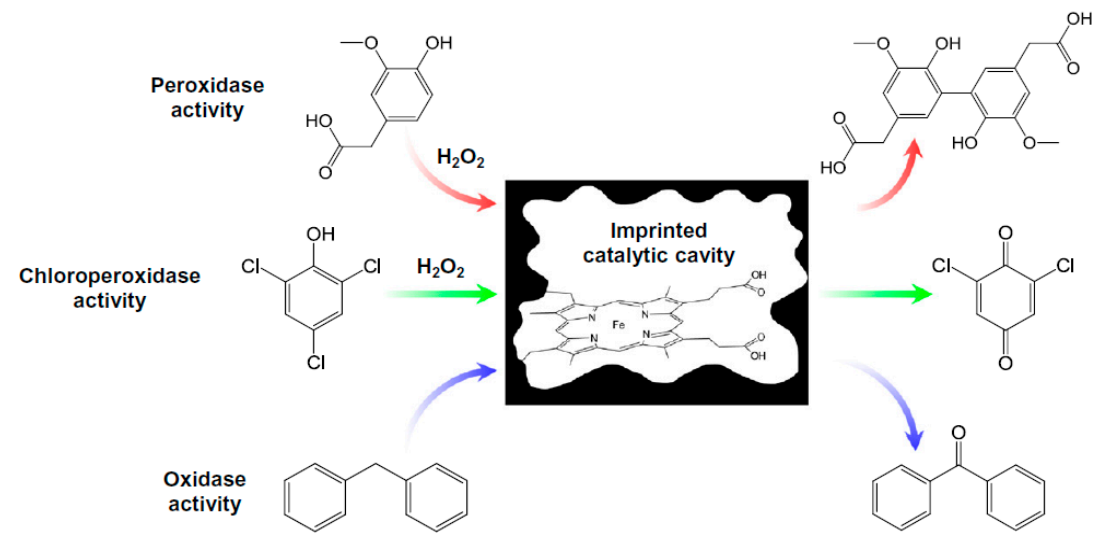

Figure 7. Hemin-based catalytically active MIPs. Reprinted by permission from [9].

Phenazine methosulfate (PMS) was used as mimic of flavine adenine dinucleotide in an amperometric MIP sensor for fructosylvaline, which is the most important long-term parameter of diabetes [110]. The signal was generated by the electrochemical reoxidation of PMS which acts as a mediator.

The catalytic function in an enzyme-mimicking MIP has also been performed by metallic nanoparticles. $\mathrm{Pt} / \mathrm{Cu}$ nanoparticles catalyzed the peroxide-dependent oxidation of MIP-bound puerarin in parallel with 3,3',5,5'-tetramethylbenzidine (TMB) [111]. Lie et al. fabricated an MIP sensor for chlortoluron on the surface of magnetic $\mathrm{NiO}$ nanoparticles, which catalyzed the oxidation of $\mathrm{H}_{2} \mathrm{O}_{2}$ [112]. Chlortoluron was detected indirectly by the effect of target binding on the $\mathrm{H}_{2} \mathrm{O}_{2}$ oxidation current. 
Recently, the integration of an MIP structure into the pores of a catalytically active Cu-based MOF has been successfully demonstrated [113]. This approach realized the specific binding of the endogeneous disruptor tetrabromobisphenol A to the MIP with an imprinting factor of 7.6. The consumption of peroxide in the MOF-catalyzed oxidation was (colorimetric) indicated. In another work, the high potential of a catalytically active framework was exemplified for the hydrolysis of highly toxic organophosphorous compounds [114]. The porous aromatic framework was 14 times more effective than the natural enzyme organophosphorous hydrolase.

The integration of the catalytically active MIPs in electrochemical sensors demonstrate that this approach has a high potential in respect to sensitivity, robustness and simple preparation.

\subsection{Redox-Inactive Analytes}

The most frequently applied method for the characterization of MIP sensors evaluates the diffusional permeability of the polymer layer to a redox marker, such as ferri/ferrocyanide, by cyclic voltammetry, differential pulse voltammetry, square wave voltammetry or electrochemical impedance spectroscopy (Figure 8) [49,56,60,115-121]. This approach is simple, cost-effective and highly sensitive. Furthermore, it provides characterization of each step of the MIP synthesis and the measurement of target rebinding to the MIP for low-molecular-weight targets, (bio)macromolecular and (nano)particles.

For low-molecular-weight molecules, the cavities after template removal have diameters comparable with that of the redox marker. Different mechanisms have been proposed for the influence of target binding on the current signal of the redox marker, including changes in the porosity of the MIP film or of the diffusion rate of the marker, doping-dedoping effects and changes in the electric double layer. The gate effect was, for the first time, described by Yoshimi et al. for a theophylline imprinted polymer, which was prepared by copolymerization of methacrylic acid and ethylene glycol dimethacrylate on an indium tin oxide electrode [122]. The model for macromolecules predicts that pores will be formed by the removal of the protein template in the tight MIP layer, which increase the permeation of the redox marker to the electrode surface. Rebinding of the target shrinks these pores, thus causing a concentration-dependent decrease in the permeation of the redox marker [37]. However, the exact mechanism of the "gate effect" is still not fully understood [122,123].

Metal organic frameworks have been applied in MIP sensors for the detection of redox-inactive analytes as well. Jiang et al. described an MIP sensor for the detection of aflatoxin B1 (AFB1), which was formed by electropolymerization of p-aminothiophenol-functionalized gold nanoparticles in the presence of the template [124]. The binding of AFB1 was indicated by linear sweep voltammetry of ferricyanide as a redox probe. The electron transfer rate increased when the concentration of AFB1 increased, due to a p-doping effect. The molecularly imprinted sensor exhibited a linear range, between $3.2 \mathrm{fM}$ and $3.2 \mu \mathrm{M}$. Recently, a polypyrrole-based MIP for $17 \beta$-estradiol has been integrated into an MOF, which was modified with Prussian Blue [125]. Together with carbon nanotubes, PB increased the electrical conductivity, which resulted in an extremely high sensitivity with an LOD of $6.19 \mathrm{fM}$. 
a)

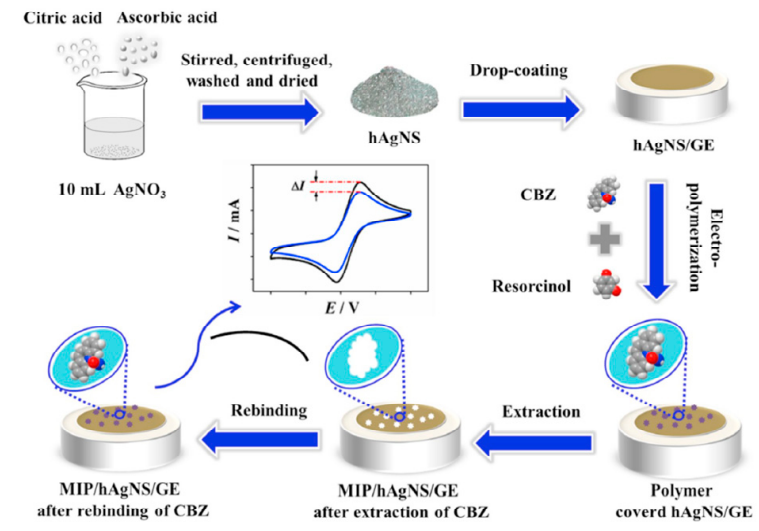

b)

c)
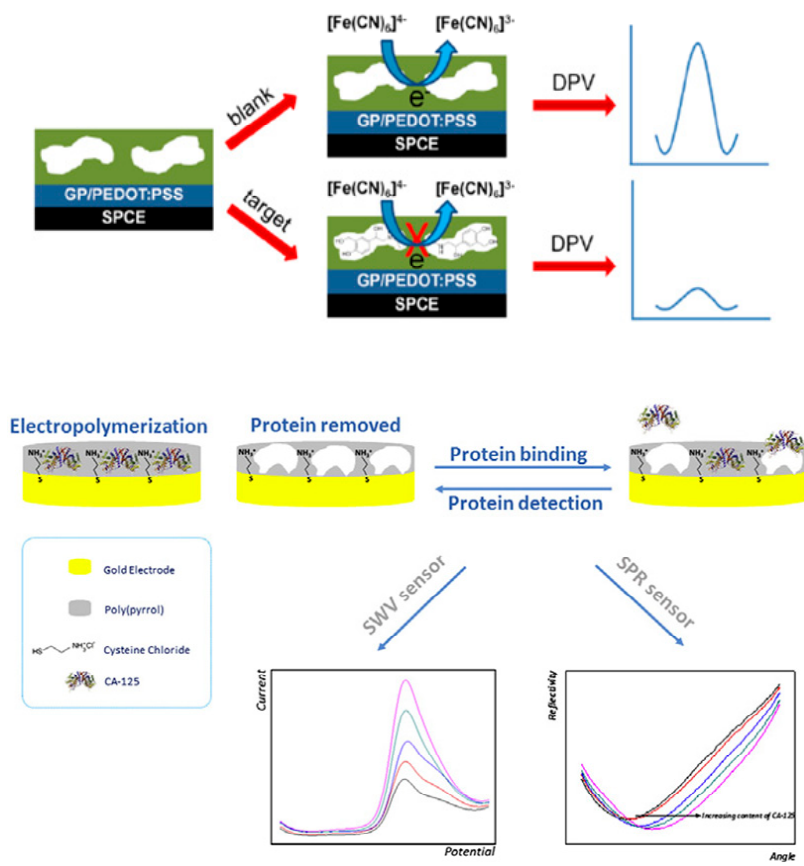

d)

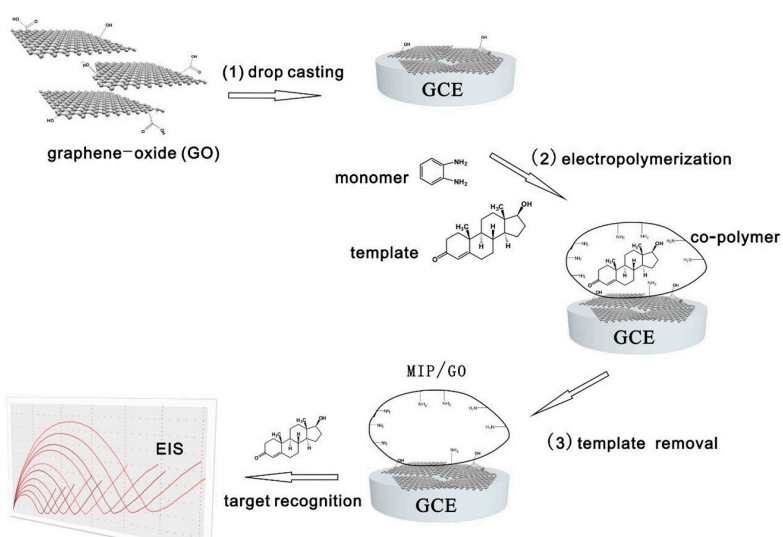

Figure 8. (a) Preparation of a carbamazepine MIP, reprinted by permission from [126]; (b) schematic representation of salbutamol MIP preparation and DPVs showing salbutamol binding to the MIP, reprinted by permission from [119]; (c) CA-125 MIP preparation by electropolymerization and SWVand SPR-based measurements, reprinted by permission from [120] and (d) testosterone MIP preparation and EIS-based determination of testosterone, reprinted by permission from [121]. 
Enhancement of the sensitivity was further achieved by electro-enzymatic recycling for an MIP for kanamycin (Figure 9) [127]. The reduced redox marker, ferrocyanide, which was formed at the electrode, was subsequently reoxidized by horseradish peroxidase (HRP) in the presence of peroxide. The enzymatic recycling brought about an eight-fold higher signal and shifted the lower limit of detection by two orders of magnitude.

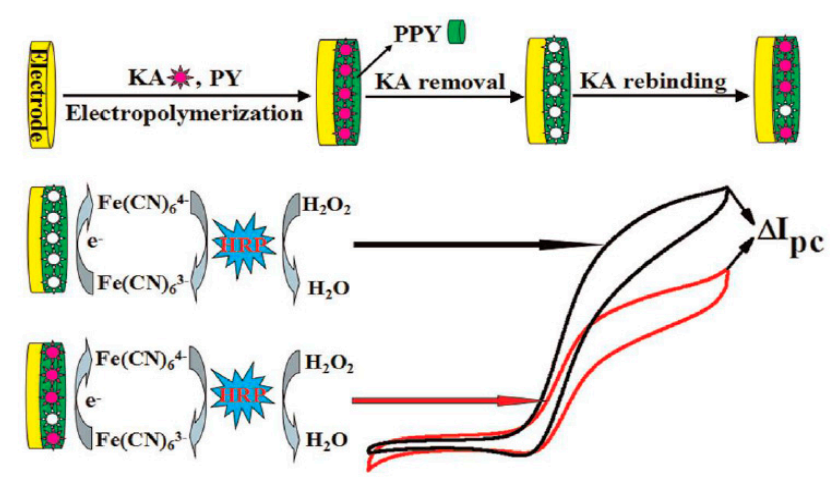

Figure 9. Preparation scheme of a kanamycin MIP using pyrrole (PPY) as a monomer, the signal is amplified by electro-enzymatic recycling of ferricyanide. Reprinted by permission from [127].

However, the analytical quality of the aforementioned approaches is problematic, since the rebinding of the target causes only small decreases in the large signal after template removal. Furthermore, the formation of "nonspecific" pores during template removal may influence the current signal. Different ionic strengths and/or $\mathrm{pH}$ during the rebinding and evaluation of the redox marker can falsify the measurement by structural changes of the polymer film. Nonspecific adsorption of surface-active constituents from the "real" sample may also influence the current. In addition, for the majority of redox marker-based MIP sensors, the signal of the redox marker is measured in a target-free solution, whereas rebinding occurs in ferricyanide-free solution. This procedure is, in principle, only applicable for MIP target systems with very low dissociation rates, which is a precondition and has been frequently ignored. Despite the inherent problems of the method, several papers describe MIP sensors for both small targets and macromolecules with lower limits of detection in the picomolar and even attomolar concentration range (Table 1). These publications evaluate either the relative or the absolute decrease in signal suppression in linear or semilogarithmic scales and frequently report two-phasic concentration dependencies without presenting a theoretical model for the binding. 
Table 1. MIPs prepared by electropolymerization with electrochemical readout.

\begin{tabular}{|c|c|c|c|c|c|}
\hline Template & Monomer & Electrode & Detection Method & Measuring Range and LOD & Reference \\
\hline Tamoxifen & o-PD/Resorcinol & GCE & $\mathrm{CV}$ & $1-100 \mathrm{nM}$ & {$[60]$} \\
\hline Lorazepam & Pyrrole & Sol-gel-AuNP-Graphite & SWV & $\begin{array}{l}0.2-2 \mathrm{nM} \\
\text { and } 2-20 \mathrm{nM} ; \\
\text { LOD: } 0.09 \mathrm{nM}\end{array}$ & [128] \\
\hline Kanamycin & $\mathrm{o}-\mathrm{PD}$ & SWCNH-GCE & LSV & $\begin{array}{l}0.1-50 \mu \mathrm{M} \\
\text { LOD: } 0.1 \mu \mathrm{M}\end{array}$ & [129] \\
\hline 2,4-dichlorophenol & $\mathrm{o}-\mathrm{PD}$ & PDA-rGO-GCE & DPV & $\begin{array}{l}2-10 \mathrm{nM} \\
\text { and } 10-100 \mathrm{nM} \text {; } \\
\text { LOD: } 0.8 \mathrm{nM}\end{array}$ & [130] \\
\hline p-Synephrine & Functionalized thiophene & Pt electrode & EIS & $\begin{array}{l}0.1-0.99 \mu \mathrm{M} ; \\
\text { LOD: } 5.69 \mathrm{nM}\end{array}$ & [115] \\
\hline Artemisinin & $\mathrm{o}-\mathrm{PD}$ & Au electrode & $\mathrm{CV}, \mathrm{SWV}$ & $\begin{array}{l}0.01-1.36 \mu \mathrm{M} ; \\
\text { LOD: } 0.01 \mu \mathrm{M}\end{array}$ & [131] \\
\hline Gemcitabine & PATP & AuNP-Au electrode & LSV & $\begin{array}{l}3.8 \mathrm{fM}-38 \mathrm{nM} \\
\text { LOD: } 3 \mathrm{fM}\end{array}$ & [132] \\
\hline Sofosbuvir & PATP & N,S@GQDs-AuNP-PGE & DPV & $\begin{array}{l}0.1-40.0 \times 10^{-8} \mathrm{M} ; \\
\text { LOD: } 0.036 \times 10^{-8} \mathrm{M}\end{array}$ & [133] \\
\hline Sulfamethoxazole & o-PD & GCE & SWV & $\begin{array}{l}0.2-1.4 \mu \mathrm{M} \\
\text { LOD: } 0.05 \mu \mathrm{M}\end{array}$ & [134] \\
\hline Lidocaine & Resorcinol & Porous C-GCE & $\mathrm{CV}$ & $\begin{array}{l}0.2 \mathrm{pM}-8 \mathrm{nM} ; \\
\text { LOD: } 67 \mathrm{fM}\end{array}$ & [135] \\
\hline Carbamazepine & Resorcinol & hAgNS-Au electrode & $\mathrm{CV}$ & $\begin{array}{l}8.0 \times 10^{-11}-6.0 \times 10^{-8} \mathrm{M} ; \\
\text { LOD: } 3.2 \times 10^{-11} \mathrm{M}\end{array}$ & [126] \\
\hline Cholesterol & PATP & AuNP-MWCNT-GCE & DPV & $\begin{array}{l}1 \times 10^{-13}-1 \times 10^{-9} \mathrm{M} ; \\
\text { LOD: } 3.3 \times 10^{-14} \mathrm{M}\end{array}$ & [136] \\
\hline Thyronamine & $4-\mathrm{ABA}$ & Carbon-SPE & SWV & $\begin{array}{l}\text { up to } 10 \mu \mathrm{M} \\
\text { LOD: } 0.081 \mu \mathrm{M}\end{array}$ & [137] \\
\hline $17-\beta$-estradiol & 3,6-diamino-9-ethylcarbazole & GCE & EIS & $\begin{array}{l}1 \mathrm{aM}-10 \mu \mathrm{M} \\
\text { LOD: } 0.36 \mathrm{aM}\end{array}$ & [138] \\
\hline Hexahydrofarnesol & $\mathrm{o}-\mathrm{PD}$ & GCE & DPV & $\begin{array}{l}4.0 \times 10^{-8}-1.5 \times 10^{-7} \mathrm{M} \text { and } \\
1.5 \times 10^{-7}-1.5 \times 10^{-6} \mathrm{M} ; \\
\text { LOD: } 1.2 \times 10^{-8} \mathrm{M}\end{array}$ & [139] \\
\hline Nitrofurantoin & m-Dihydroxy-benzene/o-Aminophenol & GCE & EIS & $\begin{array}{l}0.001-0.05 \mu \mathrm{M} \\
\text { and } 0.1-1 \mu \mathrm{M} ; \\
\text { LOD: } 0.3 \mathrm{nM}\end{array}$ & [140] \\
\hline Dibutyl phthalate & Pyrrole & PGE & EIS & $\begin{array}{l}0.01-1.0 \mu \mathrm{M} ; \\
\text { LOD: } 4.5 \mathrm{nM}\end{array}$ & [141] \\
\hline
\end{tabular}


Table 1. Cont

\begin{tabular}{|c|c|c|c|c|c|}
\hline Template & Monomer & Electrode & Detection Method & Measuring Range and LOD & Reference \\
\hline Chlorpyrifos & Pyrrole & PGE & EIS & $\begin{array}{l}20-300 \mu \mathrm{g} / \mathrm{L} ; \\
\text { LOD: } 4.5 \mu \mathrm{g} / \mathrm{L}\end{array}$ & [142] \\
\hline Transferrin & Scopoletin & Au electrode & SWV & $0.1-1 \mu \mathrm{M}$ & [49] \\
\hline HSA & Scopoletin & Au electrode & $\mathrm{CV}$ & $\begin{array}{l}20-100 \mathrm{mg} / \mathrm{dm}^{3} \\
\text { LOD: } 3.7 \mathrm{mg} / \mathrm{dm}^{3}\end{array}$ & [143] \\
\hline HSA & Bithiophene derivatives & Au electrode & DPV & $\begin{array}{l}\text { 12-300 } \mathrm{pM} ; \\
\text { LOD: } 0.25 \mathrm{pM}\end{array}$ & [144] \\
\hline Ferritin & Phenol & Nanotube arrays & EIS & $1 \times 10^{-12} \times 10^{-7} \mathrm{~g} / \mathrm{L}$ & [116] \\
\hline Annexin A3 & Caffeic acid & Carbon-SPE & SWV & $\begin{array}{l}0.1-200 \mathrm{ng} / \mathrm{mL} ; \\
\text { LOD: } 0.095 \mathrm{ng} / \mathrm{mL}\end{array}$ & [145] \\
\hline Tyrosinase & o-PD & GCE & DPV & $\begin{array}{l}\text { up to } 50 \mathrm{nM} \text {; } \\
\text { LOD: } 3.97 \mathrm{nM}\end{array}$ & {$[86]$} \\
\hline PSA & Pyrrole & Au-SPE & DPV & $\begin{array}{l}0.01-4 \mathrm{ng} / \mathrm{mL} \\
\text { LOD: } 2 \mathrm{pg} / \mathrm{mL}\end{array}$ & [146] \\
\hline CA-125 & Pyrrole & Au-SPE & SWV & $\begin{array}{l}0.01-500 \mathrm{U} / \mathrm{mL} \\
\text { LOD: } 0.01 \mathrm{U} / \mathrm{mL}\end{array}$ & [120] \\
\hline IL- $1 \beta$ & Eriochrome black T & EDOT-PATP-Carbon-SPE & EIS & $\begin{array}{l}60 \mathrm{pM}-600 \mathrm{nM} \\
\text { LOD: } 1.5 \mathrm{pM}\end{array}$ & [147] \\
\hline Protein A & 3-aminophenol & SWCNT-SPE & EIS & LOD: $0.60 \mathrm{nM}$ & [148] \\
\hline HER2-ECD & Phenol & Au-SPE & DPV & $\begin{array}{l}\text { 10-70 ng/mL; } \\
\text { LOD: } 1.6 \mathrm{ng} / \mathrm{L}\end{array}$ & [149] \\
\hline cTnT & Aniline/Carboxylated aniline & $\mathrm{rGO} / \mathrm{C}-\mathrm{SPE}$ & DPV & $\begin{array}{l}0.02-0.09 \mathrm{ng} / \mathrm{mL} ; \\
\text { LOD: } 0.008 \mathrm{ng} / \mathrm{mL}\end{array}$ & [150] \\
\hline
\end{tabular}

o-PD: o-Phenylenediamine; GCE: Glassy carbon electrode; AuNP: Gold nanoparticle; SWCNH: Single-walled carbon nanohorn; LSV: Linear sweep voltammetry; PDA-rGO: Polydopamine-reduced graphene oxide; 4-ABA: 4-Aminobenzoic acid; PATP: p-Aminothiophenol; N,S@GQDs: N,S co-doped graphene quantum dots; PGE: Pencil graphite electrode; hAgNS: Hollow silver nanospheres; SPE: Screen-printed electrode; MWCNT: Multi-walled carbon nanotubes; HSA: Human serum albumin; PSA: Prostate-specific antigen; CA-125: Carbohydrate antigen 125, IL-1 $\beta$ : Interleukin-1beta; EDOT: 3,4-Ethylenedioxythiophene; SWCNT: Single-walled carbon nanotubes; HER2-ECD: Human epidermal growth factor receptor 2; cTnT: Cardiac troponin T (cTnT) 


\section{Conclusions}

Electrochemical methods allow not only the straightforward synthesis of MIPs, including polymer formation and template removal, but also the characterization of each step and a highly sensitive readout with simple devices. MIPs are highly effective for the suppression of interferences in the electrochemical indication of low-molecular-weight analytes by acting as shape-selective filters. The indication of the "gating effect" of target binding on a redox marker, which is widely used in electrochemical MIP sensors, has the disadvantage of generating an "indirect" measuring signal. It reflects not only the presence of the target but also changes in the polymer during the interaction with the sample. On the other hand, a highly specific approach is the evaluation of an electrocatalytic current for enzymes, since it couples enzymatic activity and DET in the cavities. Until now, this principle has only been demonstrated for heme proteins. The evaluation of catalytic currents may be applied in competitive assays, which use hemin and its derivatives as the catalytic component of the tracer. The integration of catalytically active MIPs into electrochemical sensors is promising in respect to robustness, stability and costs as compared with natural enzymes.

Fully electronic MIP sensors are more common than sensors using spectroscopic methods, surface plasmon resonance or quartz crystal microbalance. In future, binding MIPs, so-called plastibodies, have the potential to substitute antibodies in affinity assays and sensors. MIP-based pocket-sized devices for critical analytes in medical emergencies and environmental supervision will adapt technologies from blood glucose meters, including self-powering by a fuel cell. Measurements by MIP sensors in real biological samples, e.g., blood, are still complicated by the presence of highly abundant proteins in the $\mathrm{g} / \mathrm{L}$ region, e.g., serum albumin and immunoglobulin, while protein markers for cancer, diabetes or heart failure are typically in the $\mathrm{mg} / \mathrm{L}$ to $\mathrm{ng} / \mathrm{L}$ range. The required sensitivity has been reported in the literature for several MIP sensors based on the readout of redox markers (Table 1). However, the majority of tests have been carried out in "artificial" urine or spiked semi-synthetic plasma. Since MIP sensors represent only one "separation plate", it is challenging to reach the required selectivity.

Author Contributions: Conceptualization, literature research, writing, reviewing and editing have been performed by A.Y. and F.W.S. All authors have read and agreed to the published version of the manuscript.

Funding: This work was funded by the Deutsche Forschungsgemeinschaft (DFG, German Research Foundation) under Germany's Excellence Strategy_EXC 2008/1 (UniSysCat) - 390540038 [Gefördert durch die Deutsche Forschungsgemeinschaft (DFG) im Rahmen der Exzellenzstrategie des Bundes und der Länder-EXC 2008/1 (UniSysCat) - 390540038].

Conflicts of Interest: The authors declare no conflict of interest.

\section{References}

1. Scheller, F.W.; Zhang, X.; Yarman, A.; Wollenberger, U.; Gyurcsányi, R.E. Molecularly imprinted polymer-based electrochemical sensors for biopolymers. Curr. Opin. Electrochem. 2019, 14, 53-59. [CrossRef]

2. Wulff, G.; Sarhan, A. Macromolecular Colloquium. Angew. Chem. Int. Ed. Engl. 1972, 11, 334-342.

3. Arshady, R.; Mosbach, K. Synthesis of Substrate-selective Polymers by Host-Guest Polymerizatioa. Rapid Commun. 1981, 692, 687-692.

4. Hayden, O.; Lieberzeit, P.A.; Blaas, D.; Dickert, F.L. Artificial antibodies for bioanalyte detection-Sensing viruses and proteins. Adv. Funct. Mater. 2006, 16, 1269-1278. [CrossRef]

5. Haupt, K.; Linares, A.V.; Bompart, M.; Bui, B.T.S. Molecularly Imprinted Polymers. In Molecular Imprinting. Topics in Current Chemistry; Haupt, K., Ed.; Springer: Berlin, Germany, 2011; pp. 1-28.

6. Dickert, F.L. Molecular imprinting and functional polymers for all transducers and applications. Sensors 2018, 18, 327. [CrossRef] [PubMed]

7. Whitcombe, M.J.; Kirsch, N.; Nicholls, I.A. Molecular Imprinting Science and Technology: A Survey of the Literature for the Years 2004-2011. J. Mol. Recognit. 2014, 27, 297-401. [PubMed]

8. Haupt, K. Imprinted polymers-Tailor-made mimics of antibodies and receptors. Chem. Commun. 2003, 9, 171-177. [CrossRef] 
9. Díaz-Díaz, G.; Antuña-Jiménez, D.; Carmen Blanco-López, M.; Jesús Lobo-Castañón, M.; Miranda-Ordieres, A.J.; Tuñón-Blanco, P. New materials for analytical biomimetic assays based on affinity and catalytic receptors prepared by molecular imprinting. TrAC Trends Anal. Chem. 2012, 33, 68-80. [CrossRef]

10. Resmini, M. Molecularly imprinted polymers as biomimetic catalysts. Anal. Bioanal. Chem. 2012, 402, 3021-3026. [CrossRef]

11. Lahcen, A.A.; Amine, A. Recent Advances in Electrochemical Sensors Based on Molecularly Imprinted Polymers and Nanomaterials. Electroanalysis 2019, 31, 188-201. [CrossRef]

12. Zhong, C.; Yang, B.; Jiang, X.; Li, J. Current Progress of Nanomaterials in Molecularly Imprinted Electrochemical Sensing. Crit. Rev. Anal. Chem. 2018, 48, 15-32. [CrossRef] [PubMed]

13. Guo, Z.; Florea, A.; Jiang, M.; Mei, Y.; Zhang, W.; Zhang, A.; Săndulescu, R.; Jaffrezic-Renault, N. Molecularly Imprinted Polymer/Metal Organic Framework Based Chemical Sensors. Coatings 2016, 6, 42. [CrossRef]

14. Anik, Ü.; Timur, S.; Dursun, Z. Metal organic frameworks in electrochemical and optical sensing platforms: A review. Microchim. Acta 2019, 186, 18-24. [CrossRef] [PubMed]

15. Yarman, A.; Turner, A.P.F.; Scheller, F.W. Electropolymers for (Nano-)Imprinted Biomimetic Biosensors; Woodhead Publishing Limited: Cambridge, UK, 2014; ISBN 9780857096609.

16. Branger, C.; Brisset, H. Advanced Electrochemical Molecularly Imprinted Polymer as Sensor Interfaces. Proceedings 2019, 15, 22. [CrossRef]

17. Kamel, A.H.; Jiang, X.; Li, P.; Liang, R. A paper-based potentiometric sensing platform based on molecularly imprinted nanobeads for determination of bisphenol A. Anal. Methods 2018, 10, 3890-3895. [CrossRef]

18. Refaat, D.; Aggour, M.G.; Farghali, A.A.; Mahajan, R.; Wiklander, J.G.; Nicholls, I.A.; Piletsky, S.A. Strategies for molecular imprinting and the evolution of MIP nanoparticles as plastic antibodies-Synthesis and applications. Int. J. Mol. Sci. 2019, 20, 304. [CrossRef] [PubMed]

19. Bokeloh, F.; Ayela, C.; Haupt, K. CHAPTER 6. Micro and Nanofabrication of Molecularly Imprinted Polymers. In Molecularly Imprinted Polymers for Analytical Chemistry Applications; Wlodzimierz, K., Sharma, P.S., Eds.; The Royal Society of Chemistry: London, UK, 2018; pp. 167-196.

20. Sharma, P.S.; Pietrzyk-Le, A.; D'Souza, F.; Kutner, W. Electrochemically synthesized polymers in molecular imprinting for chemical sensing. Anal. Bioanal. Chem. 2012, 402, 3177-3204. [CrossRef]

21. Ertürk, G.; Mattiasson, B. Molecular imprinting techniques used for the preparation of biosensors. Sensors 2017, 17, 288. [CrossRef]

22. Amatatongchai, M.; Sitanurak, J.; Sroysee, W.; Sodanat, S.; Chairam, S.; Jarujamrus, P.; Nacapricha, D.; Lieberzeit, P.A. Highly sensitive and selective electrochemical paper-based device using a graphite screen-printed electrode modified with molecularly imprinted polymers coated Fe3O4@Au@SiO2 for serotonin determination. Anal. Chim. Acta 2019, 1077, 255-265. [CrossRef]

23. Karaseva, N.A.; Pluhar, B.; Beliaeva, E.A.; Ermolaeva, T.N.; Mizaikoff, B. Synthesis and application of molecularly imprinted polymers for trypsin piezoelectric sensors. Sens. Actuators B Chem. 2019, 280, 272-279. [CrossRef]

24. Lowdon, J.W.; Eersels, K.; Rogosic, R.; Boonen, T.; Heidt, B.; Diliën, H.; van Grinsven, B.; Cleij, T.J. Surface grafted molecularly imprinted polymeric receptor layers for thermal detection of the New Psychoactive substance 2-methoxphenidine. Sens. Actuators A Phys. 2019, 295, 586-595. [CrossRef]

25. Palladino, P.; Minunni, M.; Scarano, S. Cardiac Troponin T capture and detection in real-time via epitope-imprinted polymer and optical biosensing. Biosens. Bioelectron. 2018, 106, 93-98. [CrossRef] [PubMed]

26. Lin, H.Y.; Hsu, C.Y.; Thomas, J.L.; Wang, S.E.; Chen, H.C.; Chou, T.C. The microcontact imprinting of proteins: The effect of cross-linking monomers for lysozyme, ribonuclease A and myoglobin. Biosens. Bioelectron. 2006, 22, 534-543. [CrossRef] [PubMed]

27. Crapnell, R.D.; Hudson, A.; Foster, C.W.; Eersels, K.; van Grinsven, B.; Cleij, T.J.; Banks, C.E.; Peeters, M. Recent advances in electrosynthesized molecularly imprinted polymer sensing platforms for bioanalyte detection. Sensors 2019, 19, 1204. [CrossRef] [PubMed]

28. Malitesta, C.; Mazzotta, E.; Picca, R.A.; Poma, A.; Chianella, I.; Piletsky, S.A. MIP sensors-The electrochemical approach. Anal. Bioanal. Chem. 2012, 402, 1827-1846. [CrossRef] [PubMed]

29. Saylan, Y.; Akgönüllü, S.; Yavuz, H.; Ünal, S.; Denizli, A. Molecularly imprinted polymer based sensors for medical applications. Sensors 2019, 19, 1279. [CrossRef] [PubMed]

30. Belbruno, J.J. Molecularly Imprinted Polymers. Chem. Rev. 2019, 119, 94-119. [CrossRef] 
31. Ahmad, O.S.; Bedwell, T.S.; Esen, C.; Garcia-Cruz, A.; Piletsky, S.A. Molecularly Imprinted Polymers in Electrochemical and Optical Sensors. Trends Biotechnol. 2019, 37, 294-309. [CrossRef]

32. Boysen, R.I.; Schwarz, L.J.; Nicolau, D.V.; Hearn, M.T.W. Molecularly imprinted polymer membranes and thin films for the separation and sensing of biomacromolecules. J. Sep. Sci. 2017, 40, 314-335. [CrossRef]

33. Ertürk, G.; Mattiasson, B. Capacitive biosensors and molecularly imprinted electrodes. Sensors 2017, 17, 390. [CrossRef]

34. Van Grinsven, B.; Betlem, K.; Cleij, T.J.; Banks, C.E.; Peeters, M. Evaluating the potential of thermal read-out techniques combined with molecularly imprinted polymers for the sensing of low-weight organic molecules. J. Mol. Recognit. 2017, 30, 2563. [CrossRef] [PubMed]

35. Rico-Yuste, A.; Carrasco, S. Molecularly imprinted polymer-based hybrid materials for the development of optical sensors. Polymers 2019, 11, 1173. [CrossRef] [PubMed]

36. Gui, R.; Jin, H. Recent advances in synthetic methods and applications of photo-luminescent molecularly imprinted polymers. J. Photochem. Photobiol. C Photochem. Rev. 2019, 41, 100315. [CrossRef]

37. Erdossy, J.; Horváth, V.; Yarman, A.; Scheller, F.W.; Gyurcsányi, R.E. Electrosynthesized molecularly imprinted polymers for protein recognition. TrAC Trends Anal. Chem. 2016, 79, 179-190. [CrossRef]

38. Chunta, S.; Suedee, R.; Boonsriwong, W.; Lieberzeit, P.A. Biomimetic sensors targeting oxidized-low-density lipoprotein with molecularly imprinted polymers. Anal. Chim. Acta 2020, 1116, 27-35. [CrossRef]

39. Bartold, K.; Pietrzyk-Le, A.; Lisowski, W.; Golebiewska, K.; Siklitskaya, A.; Borowicz, P.; Shao, S.; D'Souza, F.; Kutner, W. Promoting bioanalytical concepts in genetics: A TATA box molecularly imprinted polymer as a small isolated fragment of the DNA damage repairing system. Mater. Sci. Eng. C 2019, 100, 1-10. [CrossRef]

40. Sönmezler, M.; Özgür, E.; Yavuz, H.; Denizli, A. Quartz crystal microbalance based histidine sensor. Artif. Cells Nanomed. Biotechnol. 2019, 47, 221-227. [CrossRef]

41. Crapnell, R.D.; Canfarotta, F.; Czulak, J.; Johnson, R.; Betlem, K.; Mecozzi, F.; Down, M.P.; Eersels, K.; Van Grinsven, B.; Cleij, T.J.; et al. Thermal Detection of Cardiac Biomarkers Heart-Fatty Acid Binding Protein and ST2 Using a Molecularly Imprinted Nanoparticle-Based Multiplex Sensor Platform. ACS Sens. 2019, 4, 2838-2845. [CrossRef]

42. Rajkumar, R.; Katterle, M.; Warsinke, A.; Möhwald, H.; Scheller, F.W. Thermometric MIP sensor for fructosyl valine. Biosens. Bioelectron. 2008, 23, 1195-1199. [CrossRef]

43. Okan, M.; Sari, E.; Duman, M. Molecularly imprinted polymer based micromechanical cantilever sensor system for the selective determination of ciprofloxacin. Biosens. Bioelectron. 2017, 88, 258-264. [CrossRef]

44. El Kirat, K.; Bartkowski, M.; Haupt, K. Probing the recognition specificity of a protein molecularly imprinted polymer using force spectroscopy. Biosens. Bioelectron. 2009, 24, 2618-2624. [CrossRef] [PubMed]

45. Iskierko, Z.; Sharma, P.S.; Bartold, K.; Pietrzyk-Le, A.; Noworyta, K.; Kutner, W. Molecularly imprinted polymers for separating and sensing of macromolecular compounds and microorganisms. Biotechnol. Adv. 2016, 34, 30-46. [CrossRef] [PubMed]

46. Bosserdt, M.; Gajovic-Eichelman, N.; Scheller, F.W. Modulation of direct electron transfer of cytochrome c by use of a molecularly imprinted thin film. Anal. Bioanal. Chem. 2013, 405, 6437-6444. [CrossRef] [PubMed]

47. Yang, Q.; Li, J.; Wang, X.; Peng, H.; Xiong, H.; Chen, L. Strategies of molecular imprinting-based fluorescence sensors for chemical and biological analysis. Biosens. Bioelectron. 2018, 112, 54-71. [CrossRef] [PubMed]

48. Moreira, F.T.C.; Sharma, S.; Dutra, R.A.F.; Noronha, J.P.C.; Cass, A.E.G.; Sales, M.G.F. Protein-responsive polymers for point-of-care detection of cardiac biomarker. Sens. Actuators B Chem. 2014, 196, 123-132. [CrossRef]

49. Zhang, X.; Yarman, A.; Erdossy, J.; Katz, S.; Zebger, I.; Jetzschmann, K.J.; Altintas, Z.; Wollenberger, U.; Gyurcsányi, R.E.; Scheller, F.W. Electrosynthesized MIPs for transferrin: Plastibodies or nano-filters? Biosens. Bioelectron. 2018, 105, 29-35. [CrossRef]

50. Saylan, Y.; Denizli, A. Molecular fingerprints of hemoglobin on a nanofilm chip. Sensors 2018, 18, 3016. [CrossRef]

51. Chunta, S.; Suedee, R.; Singsanan, S.; Lieberzeit, P.A. Sensing array based on molecularly imprinted polymers for simultaneous assessment of lipoproteins. Sens. Actuators B Chem. 2019, 298, 126828. [CrossRef]

52. Bosserdt, M.; Erdossy, J.; Lautner, G.; Witt, J.; Köhler, K.; Gajovic-Eichelmann, N.; Yarman, A.; Wittstock, G.; Scheller, F.W.; Gyurcsányi, R.E. Microelectrospotting as a new method for electrosynthesis of surface-imprinted polymer microarrays for protein recognition. Biosens. Bioelectron. 2015, 73, 123-129. [CrossRef] 
53. Clark, L.C.; Lyons, C. Electrode Systems for Continuous Monitoring in Cardiovascular Surgery. Ann. N. Y. Acad. Sci. 1962, 102, 29-45. [CrossRef]

54. Warsinke, A.; Benkert, A.; Scheller, F.W. Electrochemical immunoassays. Fresenius. J. Anal. Chem. 2000, 366, 622-634. [CrossRef] [PubMed]

55. Ghindilis, A.L.; Smith, M.W.; Schwarzkopf, K.R.; Roth, K.M.; Peyvan, K.; Munro, S.B.; Lodes, M.J.; Stöver, A.G.; Bernards, K.; Dill, K.; et al. CombiMatrix oligonucleotide arrays: Genotyping and gene expression assays employing electrochemical detection. Biosens. Bioelectron. 2007, 22, 1853-1860. [CrossRef] [PubMed]

56. Menger, M.; Yarman, A.; Erdossy, J.; Yildiz, H.B.; Gyurcsányi, R.E.; Scheller, F.W. MIPs and aptamers for recognition of proteins in biomimetic sensing. Biosensors 2016, 6, 35. [CrossRef] [PubMed]

57. Hedborg, E.; Winquist, F.; Lundström, I.; Andersson, L.I.; Mosbach, K. Some studies of molecularly-imprinted polymer membranes in combination with field-effect devices. Sens. Actuators A Phys. 1993, 37-38, 796-799. [CrossRef]

58. Iskierko, Z.; Sharma, P.S.; Noworyta, K.R.; Borowicz, P.; Cieplak, M.; Kutner, W.; Bossi, A.M. Selective PQQPFPQQ Gluten Epitope Chemical Sensor with a Molecularly Imprinted Polymer Recognition Unit and an Extended-Gate Field-Effect Transistor Transduction Unit. Anal. Chem. 2019, 91, 4537-4543. [CrossRef] [PubMed]

59. Frasco, M.F.; Truta, L.A.A.N.A.; Sales, M.G.F.; Moreira, F.T.C. Imprinting technology in electrochemical biomimetic sensors. Sensors 2017, 17, 523. [CrossRef]

60. Yarman, A.; Scheller, F.W. The first electrochemical MIP sensor for tamoxifen. Sensors 2014, 14, 7647-7654. [CrossRef]

61. Özcan, L.; Şahin, Y. Determination of paracetamol based on electropolymerized-molecularly imprinted polypyrrole modified pencil graphite electrode. Sens. Actuators B Chem. 2007, 127, 362-369. [CrossRef]

62. Lin, L.; Lian, H.-T.; Sun, X.-Y.; Yu, Y.-M.; Liu, B. An L-dopa electrochemical sensor based on a graphene doped molecularly imprinted chitosan film. Anal. Methods 2015, 7, 1387-1394. [CrossRef]

63. Moro, G.; Bottari, F.; Sleegers, N.; Florea, A.; Cowen, T.; Moretto, L.M.; Piletsky, S.; De Wael, K. Conductive imprinted polymers for the direct electrochemical detection of $\beta$-lactam antibiotics: The case of cefquinome. Sens. Actuators B Chem. 2019, 297, 126786. [CrossRef]

64. Zembrzuska, D.; Kalecki, J.; Cieplak, M.; Lisowski, W.; Borowicz, P.; Noworyta, K.; Sharma, P.S. Electrochemically initiated co-polymerization of monomers of different oxidation potentials for molecular imprinting of electroactive analyte. Sens. Actuators B Chem. 2019, 298, 126884. [CrossRef]

65. Ghodsi, J.; Rafati, A.A. A novel molecularly imprinted sensor for imidacloprid pesticide based on poly(levodopa) electro-polymerized/TiO2 nanoparticles composite. Anal. Bioanal. Chem. 2018, 410, 7621-7633. [CrossRef] [PubMed]

66. Khadem, M.; Faridbod, F.; Norouzi, P.; Foroushani, A.R.; Ganjali, M.R.; Shahtaheri, S.J. Biomimetic electrochemical sensor based on molecularly imprinted polymer for dicloran pesticide determination in biological and environmental samples. J. Iran. Chem. Soc. 2016, 13, 2077-2084. [CrossRef]

67. Pacheco, J.G.; Castro, M.; Machado, S.; Barroso, M.F.; Nouws, H.P.A.; Delerue-Matos, C. Molecularly imprinted electrochemical sensor for ochratoxin A detection in food samples. Sens. Actuators B Chem. 2015, 215, 107-112. [CrossRef]

68. Couto, R.A.S.; Costa, S.S.; Mounssef, B.; Pacheco, J.G.; Fernandes, E.; Carvalho, F.; Rodrigues, C.M.P.; Delerue-Matos, C.; Braga, A.A.C.; Moreira Gonçalves, L.; et al. Electrochemical sensing of ecstasy with electropolymerized molecularly imprinted poly(o-phenylenediamine) polymer on the surface of disposable screen-printed carbon electrodes. Sens. Actuators B Chem. 2019, 290, 378-386. [CrossRef]

69. Kriz, D.; Mosbach, K. Competitive amperometric morphine sensor based on an agarose immobilised molecularly imprinted polymer. Anal. Chim. Acta 1995, 300, 71-75. [CrossRef]

70. Li, J.; Xu, Z.; Liu, M.; Deng, P.; Tang, S.; Jiang, J.; Feng, H.; Qian, D.; He, L. Ag/N-doped reduced graphene oxide incorporated with molecularly imprinted polymer: An advanced electrochemical sensing platform for salbutamol determination. Biosens. Bioelectron. 2017, 90, 210-216. [CrossRef]

71. Rohani Moghadam, M.; Salehi, L.; Jafari, S.; Nasirizadeh, N.; Ghasemi, J. Voltammetric sensing of oxacillin by using a screen-printed electrode modified with molecularly imprinted polyaniline, gold nanourchins and graphene oxide. Microchim. Acta 2019, 186, 798. [CrossRef] 
72. Zheng, W.; Zhao, M.; Liu, W.; Yu, S.; Niu, L.; Li, G.; Li, H.; Liu, W. Electrochemical sensor based on molecularly imprinted polymer/reduced graphene oxide composite for simultaneous determination of uric acid and tyrosine. J. Electroanal. Chem. 2018, 813, 75-82. [CrossRef]

73. Lu, Z.; Li, Y.; Liu, T.; Wang, G.; Sun, M.; Jiang, Y.; He, H.; Wang, Y.; Zou, P.; Wang, X.; et al. A dual-template imprinted polymer electrochemical sensor based on AuNPs and nitrogen-doped graphene oxide quantum dots coated on NiS2/biomass carbon for simultaneous determination of dopamine and chlorpromazine. Chem. Eng. J. 2020, 389, 124417. [CrossRef]

74. Rawool, C.R.; Srivastava, A.K. A dual template imprinted polymer modified electrochemical sensor based on $\mathrm{Cu}$ metal organic framework/mesoporous carbon for highly sensitive and selective recognition of rifampicin and isoniazid. Sens. Actuators B Chem. 2019, 288, 493-506. [CrossRef]

75. Yarman, A.; Scheller, F.W. Coupling biocatalysis with molecular imprinting in a biomimetic sensor. Angew. Chem. Int. Ed. 2013, 52, 11521-11525. [CrossRef] [PubMed]

76. Yarman, A.; Scheller, F.W. MIP-esterase/Tyrosinase Combinations for Paracetamol and Phenacetin. Electroanalysis 2016, 28, 2222-2227. [CrossRef]

77. Mazurenko, I.; Hitaishi, V.P.; Lojou, E. Recent advances in surface chemistry of electrodes to promote direct enzymatic bioelectrocatalysis. Curr. Opin. Electrochem. 2020, 19, 113-121. [CrossRef]

78. Peng, L.; Yarman, A.; Jetzschmann, K.J.; Jeoung, J.H.; Schad, D.; Dobbek, H.; Wollenberger, U.; Scheller, F.W. Molecularly imprinted electropolymer for a hexameric heme protein with direct electron transfer and peroxide electrocatalysis. Sensors 2016, 16, 272. [CrossRef] [PubMed]

79. Sun, B.; Ni, X.; Cao, Y.; Cao, G. Electrochemical sensor based on magnetic molecularly imprinted nanoparticles modified magnetic electrode for determination of $\mathrm{Hb}$. Biosens. Bioelectron. 2017, 91, 354-358. [CrossRef]

80. Pandey, I.; Tiwari, J.D. A novel dual imprinted conducting nanocubes based flexible sensor for simultaneous detection of hemoglobin and glycated haemoglobin in gestational diabetes mellitus patients. Sens. Actuators B Chem. 2019, 285, 470-478. [CrossRef]

81. Ertürk, G.; Hedström, M.; Mattiasson, B. A sensitive and real-time assay of trypsin by using molecular imprinting-based capacitive biosensor. Biosens. Bioelectron. 2016, 86, 557-565. [CrossRef]

82. Bossi, A.; Piletsky, S.A.; Piletska, E.V.; Righetti, P.G.; Turner, A.P.F. Surface-grafted molecularly imprinted polymers for protein recognition. Anal. Chem. 2001, 73, 5281-5286. [CrossRef]

83. Jetzschmann, K.J.; Yarman, A.; Rustam, L.; Kielb, P.; Urlacher, V.B.; Fischer, A.; Weidinger, I.M.; Wollenberger, U.; Scheller, F.W. Molecular LEGO by domain-imprinting of cytochrome P450 BM3. Colloids Surf. B Biointerfaces 2018, 164, 240-246. [CrossRef]

84. Jetzschmann, K.J.; Jágerszki, G.; Dechtrirat, D.; Yarman, A.; Gajovic-Eichelmann, N.; Gilsing, H.D.; Schulz, B.; Gyurcsányi, R.E.; Scheller, F.W. Vectorially Imprinted Hybrid Nanofilm for Acetylcholinesterase Recognition. Adv. Funct. Mater. 2015, 25, 5178-5183. [CrossRef]

85. Yarman, A. Electrosynthesized Molecularly Imprinted Polymer for Laccase Using the Inactivated Enzyme as the Target. Bull. Korean Chem. Soc. 2018, 39, 483-488. [CrossRef]

86. Yarman, A. Development of a molecularly imprinted polymer-based electrochemical sensor for tyrosinase. Turkish J. Chem. 2018, 42, 346-354. [CrossRef]

87. Ozcelikay, G.; Kurbanoglu, S.; Zhang, X.; Soz, C.K.; Wollenberger, U.; Ozkan, S.A.; Yarman, A.; Scheller, F.W. Electrochemical MIP sensor for butyrylcholinesterase. Polymers 2019, 11, 1970. [CrossRef] [PubMed]

88. Yang, S.; Bai, C.; Teng, Y.; Zhang, J.; Peng, J.; Fang, Z.; Xu, W. Study of horseradish peroxidase and hydrogen peroxide bi-analyte sensor with boronate affinity-based molecularly imprinted film. Can. J. Chem. 2019, 97, 833-839. [CrossRef]

89. Reddy, S.M.; Sette, G.; Phan, Q. Electrochemical probing of selective haemoglobin binding in hydrogel-based molecularly imprinted polymers. Electrochim. Acta 2011, 56, 9203-9208. [CrossRef]

90. Shumyantseva, V.V.; Bulko, T.V.; Sigolaeva, L.V.; Kuzikov, A.V.; Archakov, A.I. Electrosynthesis and binding properties of molecularly imprinted poly-o-phenylenediamine for selective recognition and direct electrochemical detection of myoglobin. Biosens. Bioelectron. 2016, 86, 330-336. [CrossRef]

91. Li, J.; Jiang, F.; Wei, X. Molecularly imprinted sensor based on an enzyme amplifier for ultratrace oxytetracycline determination. Anal. Chem. 2010, 82, 6074-6078. [CrossRef]

92. Li, J.; Jiang, F.; Li, Y.; Chen, Z. Fabrication of an oxytetracycline molecular-imprinted sensor based on the competition reaction via a GOD-enzymatic amplifier. Biosens. Bioelectron. 2011, 26, 2097-2101. [CrossRef] 
93. Li, J.; Li, Y.; Zhang, Y.; Wei, G. Highly sensitive molecularly imprinted electrochemical sensor based on the double amplification by an inorganic prussian blue catalytic polymer and the enzymatic effect of glucose oxidase. Anal. Chem. 2012, 84, 1888-1893. [CrossRef]

94. Karyakin, A.A.; Karyakina, E.E.; Gorton, L. On the mechanism of $\mathrm{H} 2 \mathrm{O} 2$ reduction at Prussian Blue modified electrodes. Electrochem. Commun. 1999, 1, 78-82. [CrossRef]

95. Que, X.; Liu, B.; Fu, L.; Zhuang, J.; Chen, G.; Tang, D. Molecular Imprint for Electrochemical Detection of Streptomycin Residues Using Enzyme Signal Amplification. Electroanalysis 2013, 25, 531-537. [CrossRef]

96. Wulff, G. Enzyme-like catalysis by molecularly imprinted polymers. Chem. Rev. 2002, 102, 1-27. [CrossRef] [PubMed]

97. Garcia Lopez, J.; Piletska, E.V.; Whitcombe, M.J.; Czulak, J.; Piletsky, S.A. Application of molecularly imprinted polymer nanoparticles for degradation of the bacterial autoinducer: N-hexanoyl homoserine lactone. Chem. Commun. 2019, 55, 2664-2667. [CrossRef] [PubMed]

98. Robinsona, D.K.; Mosbachb, K. Molecular Imprinting of a Transition State Analogue Leads to a Polymer Exhibiting Esterolytic Activity. J. Chem. Soc. Chem. Commun. 1989, 969-970. [CrossRef]

99. Mathew, D.; Thomas, B.; Devaky, K.S. Phosphonate TSA-Built Macromatric Polymer Catalysts as Chymotrypsin Mimics for the Amidolysis of Amino Acid P-Nitroanilides: Effect of the Nature and Extent of Crosslinker on Amidase Activities; Elsevier Ltd.: Amsterdam, The Netherlands, 2017; Volume 111, ISBN 9148127310.

100. Mirata, F.; Resmini, M. Metal Complexes and Imprinted Polymers for Shape-Selective Catalysis. In Effects of Nanoconfinement on Catalysis; Springer: Berlin, Germany, 2017; pp. 83-104.

101. Lakshmi, D.; Bossi, A.; Whitcombe, M.J.; Chianella, I.; Fowler, S.A.; Subrahmanyam, S.; Piletska, E.V.; Piletsky, S.A. Electrochemical sensor for catechol and dopamine based on a catalytic molecularly imprinted polymer-conducting polymer hybrid recognition element. Anal. Chem. 2009, 81, 3576-3584. [CrossRef]

102. Huang, X.; Yin, Y.; Liu, Y.; Bai, X.; Zhang, Z.; Xu, J.; Shen, J.; Liu, J. Incorporation of glutathione peroxidase active site into polymer based on imprinting strategy. Biosens. Bioelectron. 2009, 25, 657-660. [CrossRef]

103. Cheng, Z.; Zhang, L.; Li, Y. Synthesis of an enzyme-like imprinted polymer with the substrate as the template, and its catalytic properties under aqueous conditions. Chem. A Eur. J. 2004, 10, 3555-3561. [CrossRef]

104. De Jesus Rodrigues Santos, W.; Lima, P.R.; Tarley, C.R.T.; Kubota, L.T. A catalytically active molecularly imprinted polymer that mimics peroxidase based on hemin: Application to the determination of p-aminophenol. Anal. Bioanal. Chem. 2007, 389, 1919-1929. [CrossRef]

105. De Santos, W.J.R.; Lima, P.R.; Tarley, C.R.T.; Höehr, N.F.; Kubota, L.T. Synthesis and application of a peroxidase-like molecularly imprinted polymer based on hemin for selective determination of serotonin in blood serum. Anal. Chim. Acta 2009, 631, 170-176. [CrossRef]

106. Sartori, L.R.; Santos, W.D.J.R.; Kubota, L.T.; Segatelli, M.G.; Tarley, C.R.T. Flow-based method for epinephrine determination using a solid reactor based on molecularly imprinted poly(FePP-MAA-EGDMA). Mater. Sci. Eng. C 2011, 31, 114-119. [CrossRef]

107. Díaz-Díaz, G.; Diñeiro, Y.; Menéndez, M.I.; Blanco-López, M.C.; Lobo-Castañón, M.J.; Miranda-Ordieres, A.J.; Tunón-Blanco, P. Molecularly imprinted catalytic polymers with biomimetic chloroperoxidase activity. Polymer (Guildf) 2011, 52, 2468-2473. [CrossRef]

108. Zhang, J.; Lei, J.; Ju, H.; Wang, C. Electrochemical sensor based on chlorohemin modified molecularly imprinted microgel for determination of 2,4-dichlorophenol. Anal. Chim. Acta 2013, 786, 16-21. [CrossRef] [PubMed]

109. Antuña-Jiménez, D.; Blanco-López, M.C.; Miranda-Ordieres, A.J.; Lobo-Castañón, M.J. Artificial enzyme with magnetic properties and peroxidase activity on indoleamine metabolite tumor marker. Polymer (Guildf) 2014, 55, 1113-1119. [CrossRef]

110. Sode, K.; Ohta, S.; Yanai, Y.; Yamazaki, T. Construction of a molecular imprinting catalyst using target analogue template and its application for an amperometric fructosylamine sensor. Biosens. Bioelectron. 2003, 18, 1485-1490. [CrossRef]

111. Guo, L.; Zheng, H.; Zhang, C.; Qu, L.; Yu, L. A novel molecularly imprinted sensor based on PtCu bimetallic nanoparticle deposited on PSS functionalized graphene with peroxidase-like activity for selective determination of puerarin. Talanta 2020, 210, 120621. [CrossRef]

112. Li, X.; Zhang, L.; Wei, X.; Li, J. A Sensitive and renewable chlortoluron molecularly imprinted polymer sensor based on the gate-controlled catalytic electrooxidation of $\mathrm{H} 2 \mathrm{O} 2$ on Magnetic Nano-NiO. Electroanalysis 2013, 25, 1286-1293. [CrossRef] 
113. Zeng, L.; Cui, H.; Chao, J.; Huang, K.; Wang, X.; Zhou, Y.; Jing, T. Colorimetric determination of tetrabromobisphenol A based on enzyme-mimicking activity and molecular recognition of metal-organic framework-based molecularly imprinted polymers. Microchim. Acta 2020, 187, 142. [CrossRef]

114. Yuan, Y.; Yang, Y.; Faheem, M.; Zou, X.; Ma, X.; Wang, Z.; Meng, Q.; Wang, L.; Zhao, S.; Zhu, G. Molecularly Imprinted Porous Aromatic Frameworks Serving as Porous Artificial Enzymes. Adv. Mater. 2018, 30, 1-9. [CrossRef]

115. Lach, P.; Cieplak, M.; Majewska, M.; Noworyta, K.R.; Sharma, P.S.; Kutner, W. “gate Effect” in p-Synephrine Electrochemical Sensing with a Molecularly Imprinted Polymer and Redox Probes. Anal. Chem. 2019, 91, 7546-7553. [CrossRef]

116. Cai, D.; Ren, L.; Zhao, H.; Xu, C.; Zhang, L.; Yu, Y.; Wang, H.; Lan, Y.; Roberts, M.F.; Chuang, J.H.; et al. A molecular-imprint nanosensor for ultrasensitive detection of proteins. Nat. Nanotechnol. 2010, 5, 597-601. [CrossRef] [PubMed]

117. Bozal-Palabiyik, B.; Lettieri, M.; Uslu, B.; Marrazza, G. Electrochemical Detection of Vascular Endothelial Growth Factor by Molecularly Imprinted Polymer. Electroanalysis 2019, 31, 1475-1481. [CrossRef]

118. Lee, M.H.; Thomas, J.L.; Liu, W.C.; Zhang, Z.X.; Liu, B.D.; Yang, C.H.; Lin, H.Y. A multichannel system integrating molecularly imprinted conductive polymers for ultrasensitive voltammetric determination of four steroid hormones in urine. Microchim. Acta 2019, 186, 695. [CrossRef] [PubMed]

119. Dechtrirat, D.; Sookcharoenpinyo, B.; Prajongtat, P.; Sriprachuabwong, C.; Sanguankiat, A.; Tuantranont, A.; Hannongbua, S. An electrochemical MIP sensor for selective detection of salbutamol based on a graphene/PEDOT:PSS modified screen printed carbon electrode. RSC Adv. 2018, 8, 206-212. [CrossRef]

120. Rebelo, T.S.C.R.; Costa, R.; Brandão, A.T.S.C.; Silva, A.F.; Sales, M.G.F.; Pereira, C.M. Molecularly imprinted polymer SPE sensor for analysis of CA-125 on serum. Anal. Chim. Acta 2019, 1082, 126-135. [CrossRef] [PubMed]

121. Liu, W.; Ma, Y.; Sun, G.; Wang, S.; Deng, J.; Wei, H. Molecularly imprinted polymers on graphene oxide surface for EIS sensing of testosterone. Biosens. Bioelectron. 2017, 92, 305-312. [CrossRef]

122. Yoshimi, Y.; Ohdaira, R.; Iiyama, C.; Sakai, K. 'Gate effect' of thin layer of molecularly-imprinted poly(methacrylic acid-co-ethyleneglycol dimethacrylate). Sens. Actuators B Chem. 2001, 73, 49-53. [CrossRef]

123. Sharma, P.S.; Garcia-Cruz, A.; Cieplak, M.; Noworyta, K.R.; Kutner, W. 'Gate effect' in molecularly imprinted polymers: The current state of understanding. Curr. Opin. Electrochem. 2019, 16, 50-56. [CrossRef]

124. Jiang, M.; Braiek, M.; Florea, A.; Chrouda, A.; Farre, C.; Bonhomme, A.; Bessueille, F.; Vocanson, F.; Zhang, A.; Jaffrezic-Renault, N. Aflatoxin B1 detection using a highly-sensitive molecularly-imprinted electrochemical sensor based on an electropolymerized metal organic framework. Toxins 2015, 7, 3540-3553. [CrossRef]

125. Duan, D.; Si, X.; Ding, Y.; Li, L.; Ma, G.; Zhang, L.; Jian, B. A novel molecularly imprinted electrochemical sensor based on double sensitization by MOF/CNTs and Prussian blue for detection of $17 \beta$-estradiol. Bioelectrochemistry 2019, 129, 211-217. [CrossRef]

126. Chen, C.; Wang, Y.; Ding, S.; Hong, C.; Wang, Z. A novel sensitive and selective electrochemical sensor based on integration of molecularly imprinted with hollow silver nanospheres for determination of carbamazepine. Microchem. J. 2019, 147, 191-197. [CrossRef]

127. Lian, W.; Liu, S.; Wang, L.; Liu, H. A novel strategy to improve the sensitivity of antibiotics determination based on bioelectrocatalysis at molecularly imprinted polymer film electrodes. Biosens. Bioelectron. 2015, 73, 214-220. [CrossRef] [PubMed]

128. Rezaei, B.; Boroujeni, M.K.; Ensafi, A.A. A novel electrochemical nanocomposite imprinted sensor for the determination of lorazepam based on modified polypyrrole@sol-gel@gold nanoparticles/pencil graphite electrode. Electrochim. Acta 2014, 123, 332-339. [CrossRef]

129. Han, S.; Li, B.; Song, Z.; Pan, S.; Zhang, Z.; Yao, H.; Zhu, S.; Xu, G. A kanamycin sensor based on an electrosynthesized molecularly imprinted poly-o-phenylenediamine film on a single-walled carbon nanohorn modified glassy carbon electrode. Analyst 2017, 142, 218-223. [CrossRef] [PubMed]

130. Liu, Y.; Liang, Y.; Yang, R.; Li, J.; Qu, L. A highly sensitive and selective electrochemical sensor based on polydopamine functionalized graphene and molecularly imprinted polymer for the 2,4-dichlorophenol recognition and detection. Talanta 2019, 195, 691-698. [CrossRef] [PubMed]

131. Waffo, A.F.T.; Yesildag, C.; Caserta, G.; Katz, S.; Zebger, I.; Lensen, M.C.; Wollenberger, U.; Scheller, F.W.; Altintas, Z. Fully electrochemical MIP sensor for artemisinin. Sens. Actuators B Chem. 2018, 275, 163-173. [CrossRef] 
132. Florea, A.; Guo, Z.; Cristea, C.; Bessueille, F.; Vocanson, F.; Goutaland, F.; Dzyadevych, S.; Săndulescu, R.; Jaffrezic-Renault, N. Anticancer drug detection using a highly sensitive molecularly imprinted electrochemical sensor based on an electropolymerized microporous metal organic framework. Talanta 2015, 138, 71-76. [CrossRef]

133. Mahmoud, A.M.; El-Wekil, M.M.; Mahnashi, M.H.; Ali, M.F.B.; Alkahtani, S.A. Modification of N,S co-doped graphene quantum dots with p-aminothiophenol-functionalized gold nanoparticles for molecular imprint-based voltammetric determination of the antiviral drug sofosbuvir. Microchim. Acta 2019, $186,617$. [CrossRef]

134. Zhang, H.; Gui, Y.; Wang, M.L.B. Molecularly Imprinted Sensor based on o-phenylenediamine for Electrochemical Detection of Sulfamethoxazole. Int. J. Electrochem. Sci. 2019, 14, 11630-11640. [CrossRef]

135. Zhang, J.; Liu, J.; Zhang, Y.; Yu, F.; Wang, F.; Peng, Z.; Li, Y. Voltammetric lidocaine sensor by using a glassy carbon electrode modified with porous carbon prepared from a MOF, and with a molecularly imprinted polymer. Microchim. Acta 2018, 185, 3-10. [CrossRef]

136. Ji, J.; Zhou, Z.; Zhao, X.; Sun, J.; Sun, X. Electrochemical sensor based on molecularly imprinted film at Au nanoparticles-carbon nanotubes modified electrode for determination of cholesterol. Biosens. Bioelectron. 2015, 66, 590-595. [CrossRef] [PubMed]

137. Pacheco, J.G.; Rebelo, P.; Cagide, F.; Gonçalves, L.M.; Borges, F.; Rodrigues, J.A.; Delerue-Matos, C. Electrochemical sensing of the thyroid hormone thyronamine (T0AM) via molecular imprinted polymers (MIPs). Talanta 2019, 194, 689-696. [CrossRef] [PubMed]

138. Liu, W.; Li, H.; Yu, S.; Zhang, J.; Zheng, W.; Niu, L.; Li, G. Poly(3,6-diamino-9-ethylcarbazole) based molecularly imprinted polymer sensor for ultra-sensitive and selective detection of $17-\beta$-estradiol in biological fluids. Biosens. Bioelectron. 2018, 104, 79-86. [CrossRef] [PubMed]

139. Buffon, E.; Stradiotto, N.R. Electrochemical sensor based on molecularly imprinted poly(orthophenylenediamine) for determination of hexahydrofarnesol in aviation biokerosene. Sens. Actuators B Chem. 2019, 287, 371-379. [CrossRef]

140. Roushani, M.; Rahmati, Z. Development of electrochemical sensor based on molecularly imprinted copolymer for detection of nitrofurantoin. J. Iran. Chem. Soc. 2019, 16, 999-1006. [CrossRef]

141. Bolat, G.; Yaman, Y.T.; Abaci, S. Molecularly imprinted electrochemical impedance sensor for sensitive dibutyl phthalate (DBP) determination. Sens. Actuators B Chem. 2019, 299, 127000. [CrossRef]

142. Uygun, Z.O.; Dilgin, Y. A novel impedimetric sensor based on molecularly imprinted polypyrrole modified pencil graphite electrode for trace level determination of chlorpyrifos. Sens. Actuators B Chem. 2013, 188, 78-84. [CrossRef]

143. Stojanovic, Z.; Erdőssy, J.; Keltai, K.; Scheller, F.W.; Gyurcsányi, R.E. Electrosynthesized molecularly imprinted polyscopoletin nanofilms for human serum albumin detection. Anal. Chim. Acta 2017, 977, 1-9. [CrossRef]

144. Cieplak, M.; Szwabinska, K.; Sosnowska, M.; Chandra, B.K.C.; Borowicz, P.; Noworyta, K.; D’Souza, F.; Kutner, W. Selective electrochemical sensing of human serum albumin by semi-covalent molecular imprinting. Biosens. Bioelectron. 2015, 74, 960-966. [CrossRef]

145. Rebelo, T.S.C.R.; Pereira, C.M.; Sales, M.G.F.; Noronha, J.P.; Silva, F. Protein Imprinted Material electrochemical sensor for determination of Annexin A3 in biological samples. Electrochim. Acta 2016, 190, 887-893. [CrossRef]

146. Yazdani, Z.; Yadegari, H.; Heli, H. A molecularly imprinted electrochemical nanobiosensor for prostate specific antigen determination. Anal. Biochem. 2019, 566, 116-125. [CrossRef] [PubMed]

147. Cardoso, A.R.; de Sá, M.H.; Sales, M.G.F. An impedimetric molecularly-imprinted biosensor for Interleukin-1 $\beta$ determination, prepared by in-situ electropolymerization on carbon screen-printed electrodes. Bioelectrochemistry 2019, 130, 1-9. [CrossRef] [PubMed]

148. Khan, M.A.R.; Moreira, F.T.C.; Riu, J.; Sales, M.G.F. Plastic antibody for the electrochemical detection of bacterial surface proteins. Sens. Actuators B Chem. 2016, 233, 697-704. [CrossRef] 
149. Pacheco, J.G.; Rebelo, P.; Freitas, M.; Nouws, H.P.A.; Delerue-Matos, C. Breast cancer biomarker (HER2-ECD) detection using a molecularly imprinted electrochemical sensor. Sens. Actuators B Chem. 2018, 273, 1008-1014. [CrossRef]

150. Karimi, M.; Rabiee, M.; Tahriri, M.; Salarian, R.; Tayebi, L. A graphene based-biomimetic molecularly imprinted polyaniline sensor for ultrasensitive detection of human cardiac troponin T (cTnT). Synth. Met. 2019, 256, 116136. [CrossRef]

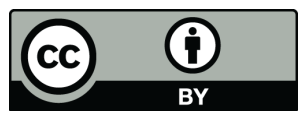

(C) 2020 by the authors. Licensee MDPI, Basel, Switzerland. This article is an open access article distributed under the terms and conditions of the Creative Commons Attribution (CC BY) license (http://creativecommons.org/licenses/by/4.0/). 